\title{
Pengaruh Disiplin Kerja Dan Lingkungan Kerja \\ Terhadap Kinerja Karyawan
}

\author{
${ }^{1}$ Sinta Herlini Putri, ${ }^{2}$ Onsardi \\ Prodi Manajemen Universitas Muhammadiyah Bengklulu \\ onsardi@umb.ac.id
}

\begin{abstract}
This study aims to determine: (1) The effect of job discipline on employee performance at The Madeline Hotel Bengkulu, (2) The effect of the job environment on employee performance on The Madeline Hotel Bengkulu, (3) The effect of job discipline and job environment partially and simultaneously on employee performance at The Madeline Hotel Bengkulu. This study is a type of research with a Quantitative Descriptive method, which the research compares the results of data collection and proves with numbers in a number of population through sample that are considered feasible to study. This study categorized into survey research, where the research instrument is a questionnaire. The sample in this study is the entire population of employees of The Madeline Hotel Bengkulu, and the number is 40 people. The validity test used Corrected Item Total Correlation Statement, Cronbach's Alpha reliability test, while data analysis uses multiple linear regression analysis. The results of thestudy showed that: (1) Job Discipline has an effect on Employee Performance. This can be seen in the t- test that states a value of t-hit $>t(\alpha /$ 2) $3,545>2,026)$ and ( $\operatorname{sig} \alpha=0.003<0.05$ ), then H1 in this study can be accepted, (2) Job Environment has an effect on Employee performance. This can be seen in the t- test which states that the value of thit $>\mathrm{t}_{-}(\alpha / 2)(4,528>2,026)$ and $(\operatorname{sig} \alpha=0,000<0.05)$, then $\mathrm{H}_{2}$ in this study is acceptable, (3) Job Discipline $\mathrm{X} 1$ and Job Environment $\mathrm{X}_{2}$ have an effect on Employee Performance (Y), this can be seen in the F- test which states the value of F-count > F-table, i.e. $(51,651>1.97)$ and $(\operatorname{sig} \alpha=0,000<0.050)$, thus it can be concludeed that $\mathrm{H} 3$ accepted that means simultaneously the Job Discipline variabel $\left(\mathrm{X}_{1}\right)$ and Job Environment $\left(\mathrm{X}_{2}\right)$ have a significant effect on Employee Performance (Y) at The Medeline Hotel Bengkulu.
\end{abstract}

Keywords: Discipline, Work Environment, Performance 


\section{BAB I \\ PENDAHULUAN}

\subsection{Latar Belakang}

Perkembangan ekonomi yang semakin pesat dewasa ini menyebabkan persaingan pasar semakin ketat. Persaingan yang ketat ini memicu setiap perusahaan untuk melakukan beberapa terobosan dalam usaha persaingan mereka terhadap perusahaan lainnya. Banyak perusahaan yang melihat bahwa tingkat dari kinerja para karyawan merupakan faktor yang menentukan dalam keberlangsungan perusahaan mereka. Melihat hal itu kita dapat mengetahui bahwa kinerja dari para karyawan sangat penting bagi perusahaan.

Sebagai kunci pokok, sumber daya manusia akan menentukan keberhasilan pelaksanaan kegiatan perusahaan. Sumber daya manusia yang baik dapat dilihat dari kinerja yang baik pula. Kinerja karyawan merupakan suatu hal penting yang harus diperhatikan demi pencapaian keberhasilan suatu perusahaan. Kinerja adalah hasil kerja secara kualitas dan kuantitas yang dicapai oleh seorang pegawai dalam melaksanakan tugasnya sesuai dengan tanggung jawab yang diberikan kepadanya.

Menurut Tika (2006), kinerja merupakan suatu fungsi dari motivasi dan kemampuan untuk menyelesaikan tugas dan pekerjaan, seseorang harus memiliki derajat kesediaan dan tingkat kemampuan. Menurut Ciptoningrum (2013), sumber daya manusia mempunyai peran utama dalam setiap kegiatan perusahaan. Walaupun didukung dengan sarana dan prasarana serta sumber dana yang berlebihan, tetapi tanpa dukungan sumber daya manusia yang andal kegiatan perusahaan tidak akan terselesaikan dengan baik. Hal ini menunjukkan bahwa sumber daya manusia merupakan kunci pokok yang harus diperhatikan kebutuhannya. 
Kinerja adalah hasil-hasil fungsi pekerjaan seseorang atau kelompok dalam suatu organisasi pada periode waktu tertentu yang merefleksikan seberapa baik seseorang atau kelompok tersebut memenuhi persyaratan sebuah pekerjaan dalam usaha pencapaian tujuan organisasi (Bernardin dan Russell, 2002). Bernardin dan Russell mengemukakan beberapa indikator yang digunakan untuk mengukur kinerja karyawan dalam penelitian ini di antaranya yaitu kualitas kerja, kuantitas kerja, pengetahuan, dan kerjasama.

Seorang karyawan atau pekerja tentu dituntut untuk bisa bekerja sesuai dengan standar yang telah ditetapkan suatu perusahaan, sebab kinerja yang baik adalah kinerja optimal yang membantu tercapainya tujuan ataupun target dari sebuah perusahaan. Agar kinerja karyawan selalu konsisten maka setidak-tidaknya organisasi selalu memperhatikan lingkungan kerja disekitar karyawan yang dapat mempengaruhi kemampuan seseorang dalam menjalankan tugasnya serta disiplin kerja yang tinggi dari karyawan tersebut.

Disiplin kerja adalah sikap, tingkah laku, dan perbuatan yang sesuai dengan peraturan organisasi baik tertulis maupun tidak tertulis (Sutrisno, 2009,p.89). Pandangan lain menyatakan bahwa disiplin kerja adalah suatu alat yang digunakan para manajer untuk berkomunikasi dengan karyawan agar bersedia mengubah perilaku serta berbagai upaya untuk meningkatkan kesadaran dan kesediaan seseorang mentaati semua peraturan perusahaan dan norma-norma sosial yang berlaku (Rivai \& Sagala, 2009,p.825). Menurut Rivai (2005) mengemukakan bahwa indikator yang digunakan untuk mengukur disiplin kerja adalah kehadiran, ketaatan pada peraturan kerja, ketaatan pada standar kerja, tingkat kewaspadaan tinggi, dan bekerja etis.

Selain dipengaruhi oleh disiplin kerja, kinerja karyawan juga dipengaruhi oleh lingkungan kerja. Dalam kaitan ini Sedarmayanti (2017:26) mengemukakan bahwa lingkungan kerja dapat mempengaruhi suatu kinerja pegawai karena seorang manusia akan mampu melaksanakan kegiatan dengan baik, sehingga dicapai suatu hasil yang optimal apabila ditunjukan suatu kondisi lingkungan yang sesuai.

Lingkungan kerja memiliki arti yaitu keseluruhan alat perkakas dan bahan yang dihadapi, lingkungan sekitarnya dimana seseorang bekerja, metode kerjanya, serta pengaturan kerja yang baik sebagai perseorangan maupun sebagai perkelompok. Selanjutnya dikatakan Sedarmayanti bahwa kondisi lingkungan dikatakn baik atau sesuai apabila manusia dapat melaksanakan kegiatannya secara optimal, sehat, aman dan nyaman. Kegiatan lingkungan yang kurang baik dapat menuntut tenaga dan waktu yang lebih banyak dan tidak mendukung diperolehnya rancangan sistem yang efesien. Sedangkan menurut Herman Sofyandi (2008) definisi lingkungan kerja adalah suatu bentuk sususnan atau rangkaian faktor yang menjadi pengaruhi kinerja, yang bisa dilihat dari fungsi, aktivitas manajemen dalam organisasi.

Menurut Darvis dalam Ragil (2013:2) lingkungan kerja dalam suatu organiasi mempunyai arti penting bagi individu yang bekerja di dalamnya. Lingkungan kerja yang sesuai dapat mendukung pelaksanaan kerja sehingga karyawan memiliki semangat bekerja dan meningkatkan kinerja karyawan, sedangkan ketidaksesuaian lingkungan kerja dapat menciptakan ketidanyamanan bagi karyawan dalam melaksanakan tugas-tugasnya.

Menjalankan perusahaan perhotelan dituntut untuk terus melakukan pembenahan diberbagai aspek terutama dibidang SDM. Salah satu perusahaan yang bergerak dibidang perhotelan adalah The Madeline Hotel Bengkulu yang beralamat di Jl. Bakti Husada No. 88, Lingkar Barat, Gading Cempaka, Kota Bengkulu. Perusahaan ini didirikan pada tahun 1998 dengan lokasi yang strategis yaitu di jalan Bakti Husada dimana menjadi lokasi yang tepat untuk singgah dan bermalam. The Madeline Hotel Bengkulu memiliki kamar dengan jumlah 36 dan karyawan dengan jumlah 40 orang. Dari jumlah karyawan tersebut dibagi ke dalam beberapa 
bagian yaitu, general manager, asisten RDM, asisten SMM, accounting coordinator, SOUS CHEF dan ENG SPV.

Berdasarkan kegiatan survei awal yang dilakukan oleh peneliti di The Madeline Hotel Bengkulu pada bulan januari 2019 dengan menggunakan metode wawancara kepada pengunjung The Madeline Hotel Bengkulu diperoleh beberapa informasi tentang kurangnya disiplin kerja karyawan The Madeline Hotel Bengkulu yang dibuktikan dengan salah satu kamar dengan no 101 alas tempat tidurnya kotor dan juga kurang disiplinnya kerja karyaan yang dibuktikan dengan ketidaktepatan waktu penyelesaian pekerjaan oleh karyawan. Masih terdapat beberapa karyawan yang kesulitan untuk mengatasi seluruh keinginan dari tamu-tamu serta untuk dapat menyelesaikan pekerjaan tepat waktu. Selain itu permasalahan yang terdapat di The Madeline Hotel Bengkulu adalah kurang kondusifnya lingkungan kerja The Madeline Hotel Bengkulu dapat dilihat dari AC di beberapa ruangan ada yang mati dan beberapa air sower mati di pagi hari sehingga menyebabkan ketidaknyamanan pengunjung hotel.

Setelah uraian dan penjelasan singkat diatas maka penulis tertarik untuk mengetahui adanya pengaruh antara variabel yang di sebutkan di atas sehingga memutuskan untuk melakukan penelitian dengan judul "Pengaruh Disiplin Kerja Dan Lingkungan Kerja Terhadap Kinerja Karyawan Pada The Madeline Hotel Bengkulu”.

\subsection{Batasan Masalah}

Berdasarkan latar belakang di atas, terlihat bahwa disiplin kerja dan lingkungan kerja merupakan masalah utama yang mempengaruhi kinerja karyawan. Dengan alasan tersebut, maka peneliti membatasi masalah penelitian pada "Pengaruh Disiplin Kerja Dan Lingkungan Kerja Terhadap Kinerja Karyawan (studi kasus pada karyawan The Madeline Hotel Bengkulu)". Kinerja karyawan dipilih karena dengan kinerja karyawan The Madeline Hotel Bengkulu yang meningkat, maka target dan tujuan dari The Madeline Hotel Bengkulu pun dapat tercapai.

\subsection{Rumusan Masalah}

Adapun rumusan masalah dari latar belakang di atas adalah sebagai berikut:

1. Apakah disiplin kerja berpengaruh terhadap kinerja karyawan pada The Madeline Hotel Bengkulu?

2. Apakah lingkungan kerja berpengaruh terhadap kinerja karyawan pada The Madeline Hotel Bengkulu?

3. Apakah disiplin kerja dan lingkungan kerja secara parsial dan simultan berpengaruh terhadap kinerja karyawan pada The Madeline Hotel Bengkulu?

\subsection{Tujuan Penelitian}

Adapun tujuan dari rumusan masalah di atas adalah sebagai berikut:

1. Untuk mengetahui pengaruh disiplin kerja terhadap kinerja karyawan pada The Madeline Hotel Bengkulu.

2. Untuk mengetahui pengaruh lingkungan kerja terhadap kinerja karyawan pada The Madeline Hotel Bengkulu.

3. Untuk mengetahui pengaruh disiplin kerja dan lingkungan kerja secara parsial dan simultan terhadap kinerja karyawan pada The Madeline Hotel Bengkulu. 


\subsection{Manfaat Penelitian}

Dengan tercapainya tujuan-tujuan tersebut, maka penelitian ini diharapkan akan memberikan manfaat sebagai berikut:

1. Secara Teoritis

Sarana untuk memberikan bukti emperis tentang pengaruh disiplin dan lingkungan kerja terhadap kinerja karyawan. Penelitian ini juga diharapkan menjadi refrensi dan memberikan sumbangan-sumbangan konseptual bagi peneliti sejenis maupun cipitas academia lainnya dalam rangka mengembangkan ilmu pengetahuan untuk pengembangan dan kemajuan dunia pendidikan.

2. Secara Praktis

Dapat memberikan gambaran pengetahuan informasi yang mendalam bagi perusahaan, mahasiswa dan para akademisi mengenai pengaruh displin kerja dan lingkungan kerja karyawan. Selain itu dapat dijadikan bahan evaluasi bagi manajer The Madeline Hotel Bengkulu agar dapat mengambil keputusan dan menerapkan kebijakan yang tepat dalam ragka meningkatkan kinerja karyawannya. 


\section{BAB II \\ STUDI PUSTAKA}

\subsection{Deskripsi Konseptual}

Konseptual adalah penjelasan tentang variabel-variabel yang digunakan dalam penelitian secara sistematik dan mengkaji tentang teori, hasil penelitian sebelumnya, kerangka pemikiran, definisi operasional dan hipotesis.

\subsubsection{Kinerja Karyawan}

Kinerja dapat diartikan sebagai hasil pencapaian sesuai dengan standart yang berlaku pada organisasi. Menurut Sedarmayanti (2011:260) kinerja merupakan terjemahan dari performance yang berarti hasil kerja seorang pekerja, sebuah proses manajemen atau suatu organisasi secara keseluruhan, dimana hasil kerja tersebut harus dapat ditunjukkan buktinya secara konkrit dan dapat diukur (dibandingkan dengan standar yang telah ditentukan).

Menurut Sutrisno (2010) dan (Onsardi, 2019). Kinerja adalah kesuksesan seseorang dalam melaksanakan tugas, hasil kerja yang dapat dicapai oleh seseorang atau sekelompok orang dalam suatu organisasi sesuai dengan wewenang dan tanggung jawab masing-masing atau tentang bagaimana seseorang diharapkan dapat berfungsi dan berperilaku sesuai dengan tugas yang telah dibebankan kepadanya serta kuantitas, kualitas dan waktu yang digunakan dalam menjalankan tugas.

Bangun (2012) dan Anjani, R. (2019) mengatakan kinerja adalah hasil pekerjaan yang dicapai seseorang berdasarkan persyaratan-persyaratan pekerjaan, persyaratan biasa disebut dengan standar kerja, yaitu tingkat yang diharapkan suatu pekerjaan tertentu untuk dapat diselesaikan dan diperbandingan atas tujuan atau target yang ingin dicapai.

Menurut Sudarmanto (2009), kinerja merupakan catatan hasil yang diproduksi/dihasilkan atas fungsi pekerjaan tertentu atau aktivitas-aktivitas selama periode waktu tertentu dan seperangkat perilaku yang relevan dengan tujuan organisasi. Sedangkan menurut Wilson (2012:131) kinerja adalah hasil pekerjaan yang seorang berdasarkan persyaratan-persyaratan pekerjaan (job requirement). Suatu perkerjaan mempunyai persyaratan tertentu untuk dapat dilakukan dalam mencapai tujuan-tujuan yang disebut juga sebagai standar (job standart).

Menurut Anwar Prabu Mangkunegara (2015:67) dalam bukunya Manajemen Sumber Daya Manusia Perusahaan, mengemukakan pengertian kinerja adalah hasil kerja secara kualitas dan kuantitas yang dicapai oleh seorang karyawan dalam melaksanakan tugasnya sesuai dengan tanggung jawab yang diberikannya.

Dari beberapa definisi tentang kinerja di atas, dapat disimpulkan bahwa kinerja adalah prestasi atau hasil kerja baik kualitas maupun kuantitas yang dicapai sumber daya manusia dalam melaksanakan tugasnya sesuai dengan standart dan tanggung jawab yang diberikan kepadanya.

Menurut Setiawan (2014:1477) untuk mengukur kinerja dapat menggunakan indikator-indikator sebagai berikut:

1. Ketepatan penyelesaian tugas/pengelolaan waktu dalam bekerja dan juga ketepatan karyawan dalam penyelesaian pekerjaan.

2. Kesesuaian jam kerja merupakan kesediaan karyawan dalam mematuhi peraturan perusahaan yang berkaitan dengan ketepatan waktu masuk/pulang kerja dengan dan jumlah kehadiran. 
3. Tingkat kehadiran dapat dilihat dari jumlah ketidakhadiran karyawan dalam suatu perusahaan selama priode tertentu.

4. Kerjasama antar karyawan merupakan kemampuan karyawan untuk berkerja sama dengan orang lain dalam menyelesaikan suatu tugas yang ditentukan sehingga mencapai daya guna dan hasil guna yang sebesar-besarnya.

Faktor-faktor yang dapat mempengaruhi kinerja karyawan menurut Kasmir (2016) sebagai berikut:

1. Kemampuan dan keahlian

Merupakan kemampuan atau skil yang dimiliki seseorang dalam melakukan suatu pekerjaan. Semakin memiliki kemampuan dan keahlian maka dapat menyelesaikan pekerjaannya secara benar, sesuai dengan yang telah ditetapkan.

2. Pengetahuan

Pengetahuan tentang pekerjaan. Seseorang yang memiliki pengetahuan tentang pekerjaan secara baik akan memberikan hasil kerja yang baik, dengan demikian pula sebaliknya.

3. Rancangan Kerja

Merupakan rancangan pekerjaan yang akan memudahkan karyawan dalam mencapai tujuannya.

4. Kepribadian

Yaitu kepribadiaan seseorang atau karakter yang dimiliki seseorang.

5. Motivasi Kerja

Merupakan dorongan bagi seseorang untuk melakukan pekerjaan. Jika karyawan memiliki dorongan yang kuat dari dalam dirinya atau dorongan dari luar dirinya (misalnya dari pihak perusahan), maka karyawan akan terangsang atau terdorong melakukan sesuatu yang baik.

6. Kepemimpinan

Merupakan prilaku seseorang pemimpin dalam mengatur, mengelolah dan memerintah bawahannya untuk mengerjakan sesuatu tugas dan tanggung jawab yang diberikannya.

7. Gaya Kepemimpinan

Merupakan gaya atau sikap seseorang pemimpin dalam menghadapi atau memerintahkan bawahannya.

8. Budaya Organisasi

Merupakan kebiasaan-kebiasaan atau norma yang berlaku dan dimiliki oleh suatu organisasi atau perusahaan.

9. Kepuasan Kerja

Merupakan perasaan senang atau gembira atau perasaan suka seseorang sebelum dan setelah melakukan suatu pekerjaan.

10. Lingkungan kerja

Merupakan suasana atau kondisi disekitar lokasi tempat berkerja. Lingkungan kerja dapat berupa ruangan, layout, sarana dan prasarana.

11. Loyalitas

Merupakan kesetiaan karyawan untuk tetap bekerja dn membela perusahaan dimana tempatnya bekerja.

12. Komitmen

Merupakan kepatuhan karyawan untuk menjalankan kebijakan atau praturan perusahaan dalam bekerja.

13. Disiplin Kerja 
Merupakan usaha karyawan untuk menjalankan aktivitas kerjanya secara sunguh-sungguh. Disiplin kerja dalam hal ini dapat berupa waktu, misalnya masuk kerja sealu tepat waktu.

\subsubsection{Disiplin Kerja}

Disiplin menunjukan suatu kondisi atau sikap hormat yang ada pada diri karyawan terhadap peraturan dan ketetapan perusahaan. Dengan demikian bila peraturan atau ketetapan yang ada dalam perusahaan diabaikan, atau sering dilanggar, maka karyawan mempunyai disiplin yang buruk. Sebaliknya bila karyawan tunduk pada ketetapan perusahaan menggambarkan adanya kondisi disiplin yang baik. Menurut Singodimedjo dalam Edi Sutrisno (2016:86), menyatakan bahwa disiplin adalah sikap kesediaan atau kerelaan seseorang untuk mematuhi dan menaati norma-norma peraturan yang berlaku disekitarnya. Sedangkan menurut Malayu Hasibuan (2012:193), kedisiplinan adalah kesadaran dan kesediaan seseorang menaati semua peraturan perusahaan dan norma-norma sosial yang berlaku.

Edi Sutrisno (2016:89) menjelaskan disiplin adalah prilaku seseorang sesuai dengan peraturan, prosedur kerja yang ada atau disiplin adalh sikap, tingkah laku, dan perbuatan yang sesuai dengan peraturan dari organisasi baik tertulis maupun tidak tertulis. Sedangkan menurut Rivai (2011:825) bahwa disiplin kerja adalah suatu alat yang dipergunakan para manajer untuk berkomunikasi dengan karyawan agar mereka bersedia untuk mengubah suatu perilaku serta sebagai suatu upaya untuk meningkatkan kesadaran dan kesedian seorang dalam memenuhi segala peraturan perusahaan.

Berdasarkan definisi disiplin kerja di atas dapat disimpulkan bahwa disiplin kerja merupakan suatu sikap yang sesuai dengan standart peraturan dan norma yang berlaku di organisasi, dan jika ada yang melanggar maka akan diberi sanksi.

Menurut Hasibuan (2013:194) indikator-indikator disiplin kerja terdiri dari:

1. Selalu datang dan pulang tepat pada waktunya

Ketetapan pegawai datang dan pulang sesuai dengan aturan dapat dijadikan ukuran disiplin kerja dengan selau datang dan pulang tepat dengan waktunya atau sesuai dengan aturan yang telah ditetapkanmaka dapat mengindikasikan baik tidaknya tingkat kedisiplinan dalam organisasi tersebut.

2. Mengerjakan semua pekerjaan dengan baik

Mengerjakan semua pekerjaan dengan baik manjadi salah satu indikator kedisiplinan, dengan hasil pekerjaan yang baik dapat menunjukan kedisiplinan pegawai suatu organisasi dalam mengerjakan tugas yang diberikan.

3. Mematuhi semua organisasi dan norma-norma yang berlaku

Mematui semua peraturan organisasi dan norma-norma berlaku merupakan salah satu sikap disiplin pegawai sehingga apabila pegawai tersebut tidak mematuhi aturan dan melanggar norma-norma yang berlaku maka itu menujukan adanya sikap tidak disiplin.

Faktor-faktor yang mempengaruhi disiplin kerja menurut Hasibuan (2013:194), menyatakan bahwa pada dasarnya banyak indikator yang memepengaruhi tingkat kedisiplinan karyawan suatu organisasi, diantaranya adalah:

1. Tujuan dan kemampuan

Tujuan dan kemampuan ikut memepengaruhi tingkat kedisiplinan karyawan. Tujuan yang akan dicapai harus jelas dan ditetapkan secara ideal serta cukup menantang bagi kemapuan karyawan. Hal ini berarti bahwa tujuan (pekerjaan) yang dibebabankankepada karyawan harus sesuai dengan 
kemampuan karyawan yang bersangkutan, agar dia berkerja sungguhsungguh dan disiplin dalam pekerjaan.

2. Teladan pimpinan

Teladan pimpinan sangat berperan dalam menetukan kedisiplinan karyawan karena pimpinan dijadikan teladan dan panutan oleh para bawahannya. Pimpinan harus memberi contoh yang baik, disiplin, baik, jujur, adil serta sesuai dengan perbuatan. Dengan teladan pimpinan yang baik, kedisiplinan bawahan akan ikut baik. Jika teladan pimpinan kurang baik, para bawahan pun akan kurang disiplin.

3. Balas jasa

Balas jasa (gaji dan kesejateraan) ikut memepengaruhi kedisiplinan karyawan karena balas jasa akan memberikan kepuasan dan kecintaan karyawan terhadap perusahaan/pekerjaannya jika kecintaan karyawan semakin baik terhadap pekerjaan, kedisiplinnan mereka akan baik pula.

4. Keadilan

Keadilan ikut mendorong terwujudnya kedisiplinan karyawan karena ego dan sifat manusia yang selalu merasa dirinya penting dan minta diperlakukan sama dengan manusia lainnya.

5. Waskat

Waskat (pengawaan melekat) adalah tindakan nyata yang paling efektif dalam mewujudkan kedisiplinan karyawan. Dengan waskat berarti atasan harus akif dan langsung mengawasi prilaku, moral, sikap, gairah kerja, dan prestasi kerja bawahannya. Hal ini berarti atasan harus selalu ada ditempat kerja agar dapat mengawasi dan memeberikan petunjuk, jika ada bawahannya mengalami kesulitan dalam menyelesaikan pekerjaannya.

6. Sanksi hukuman

Sanksi hukuman berperan penting dalam memelihara kedisiplinan karyawan. Dengan sanksi hukuman yang semakin berat, karyawan akan semakin takut melanggar peraturan-peraturan perusahaan, sikap, dan prilaku indispliner karyawan akan berkurang.

7. Ketegasan

Ketegasan pimpinan dalam melakukan tindakan akan mempengaruhi kedisiplinan karyawan perusahaan karyawan. Pimpinan harus tegas, bertindak untuk menghukum setiap karyawan yang idiskliner sesuai dengan saksi hukuman telah ditetapkan. Pempinan yang berani bertindak tegas menerapkan hukuman karyawan yang indispliner yang disegani dan dakan diakui kepemimpinannya oleh bawahannya. Dengan demikian pimpinan akan memelihara karyawan perusahaan.

8. Hubungan kemanusiaan

Hubungan kemanusiaan yang harmonis diantaranya sesame karyawan ikut menciptakan kedisiplinan yang baik pada satu perusahaan. Hubunganhubungan yang baik bersifatnya vertical maupun horizontal yang terdiri dari direct single relationship, direct group relationship dan cross relationship hendaknya harmonis.

\subsubsection{Lingkungan Kerja}

Lingkungan kerja mempengaruhi kinerja pegawai. Lingkungan kerja yang kondusif memberikan rasa aman dan memungkinkan para pegawai untuk dapat berkerja optimal. Lingkungan kerja mempunyai pengaruh langsung terhadap pegawai dalam 
menyelesaikantanggung jawab kepada organisasi. Lingkungan kerja merupakan segala sesuatu yang ada disekitar para pekerja dan yang dapat mempengaruhi dirinya dalam menjalankan tugas-tugas yang dibebanka, misalnya kebersihan, musik, penerangan dan lain-lain (Sunyoto, 2013:43).

Menurut Robins (2010) lingkungan adalah lembaga-lembaga atau kekuatankekuatan di luar yang berpotensi mempengaruhi kinerjaorganisasi lingkungan dirumuskan menjadi dua yaitu lingkungan umum dan lingkungan khusus. Lingkungan umum adalah segala sesuatu di luar organisasi yang memiliki potensi mempengaruhi organisasi. Lingkungan ini berupa kondisi sosial dan teknologi. Sedangkan lingkungan kerja khusus adalah bagian lingkungan yang secara langsung berkaitan dengan pencapaoian sasaran-sasaran sebuah organisasi.

Menurut Sutrisno (2010) menyatakan bahwa lingkungan kerja adalah keseluruhan sarana dan prasarana kerja yang ada di sekitar karyawan yang sedang melakukan pekerjaan yang dapat mempengaruhi pelaksanaan pekerjaan, lingkungan kerja ini meliputi tempat bekerja, fasilitas, dan alat bantu pekerjaan, kebersihan, pencayahaan, ketenangan, termasuk juga hubungan kerja antar karyawan. Sedangkan menurut Sedarmayanti (2009:21) definisi lingkungan kerja adalah keseluruhan alat perkakas dan bahan yang dihadapi, lingkungan sekitarnya di mana seseorang bekerja, metode kerjanya, serta pengaturan kerjanya baik sebagai perseorangan maupun sebagai kelompok.

Menurut Nitisemito dalam Dwi Agung Nugroho Arianto (2013) lingkungan kerja adalah segala sesuatu yang ada disekitar karyawan dan dapat mempengaruhi dalam menjalankan tugas yang diembankan kepadanya misalnya dengan adanya air conditioner (AC), penerangan yang memadai dan sebagainya.

Berdasarkan pengertian di atas dapat disimpulkan bahwa lingkungan kerja merupakan lingkungan yang ada pada peerusahaan yang menunjukkan tempat dan aktivitas karyawan dalam bekerja, baik sarana maupun prasarana dalam bekerja.

Lingkungan kerja di perusahaan terbagi kedalam dua demensi, yaitu lingkungan kerja fisik dan lingkungan kerja non fisik.Lingkungan kerja fisik adalah semua keadaan berbentuk fisik yang terdapat di sekitar tempat kerja dan dapat mempengaruhi karyawan. Siagan (2014:59) mengemukan bahwa demensi lingkungan kerja fisik terdiri dari beberapa indikator, yaitu:

1. Bangunan tempat kerja

Bangunan tempat kerja di samping menarik untuk dipandang juga dibangun dengan pertimbangan keselamat kerja agar karyawan merasa nyaman dan aman dalam melakukan pekerjaannya.

2. Peralatan kerja yang memadai

Peralatan yang memadai sangat dibutuhkan oleh karyawan karena akan mendukung karyawan dalam menyelesaikan tugas yang di embannya di dalam perusahaan.

3. Fasilitas

Fasilitas perusahaan sangat dibutuhkan oleh karyawan sebagai pendukung dalam menyelesaikan pekerjaan yang ada di perusahaan. Selain itu ada hal yang perlu diperhatikan oleh perusahaan yakni tentang cara memanusiakan karyawannya, seperti tersediaanya fasilitas untuk karyawan beristirahat setelah lelah bekerja dan juga tersedianya tempat ibadah.

4. Tersedianya sarana angkutan 
Tersedianya sarana angkutan akan mendukung para karyawan untuk sampai di tempat kerja dengan tepat waktu baik yang diperuntukan karyawan maupun angkutan umum yang nyaman, murah dan mudah di peroleh.

Menurut Sagian (2014:61) mengemukakan bahwa dimensi lingkungan kerja non fisik terdiri dari beberapa indikator yaitu:

1. Hubungan rekan kerja setingkat Indikator hubungan dengan rekan kerja yaitu hubungn dengan rekan kerja yang harmonis dan tanpa saling intrik diantara sesame rekan kerja. Salah satu faktor yang dapat memepengaruhi karyawan tetap tinggal dalam satu organisasi adalah adanya hubungan yang harmonis dan kekeluargaan.

2. Hubungan atasan dengan karyawan

Hubungan atasan dengan bawahan atau kryawannya harus dijaga dengan baik dan harus saling menghargai antara atasan dengan bawahan, dengan saling menghargai maka akan menimbulkan rasa hormat diantar individu masing-masing.

3. Kerja sama antar karyawan

Kerja sama antara karyawan harus dijaga dengan baik, karena akan mempengaruhi kerja yang mereka lakukan. Jika kerja sama antara karyawan dapat terjalin dengan baik maka karyawan dapat menyelesaikan pekerjaan mereka secara efektif dan efesien.

Menurut Sunyoto (2013:44) ada beberapa faktor yang berkaitan dengan lingkungan kerja, yaitu:

1. Hubungan karyawan

Dalam hubungan karyawan ini terdapat dua hubungan yaitu hubungan sebagai individu dan hubungan sebagai kelompok. Hubungan sebagai individu yaitu motivasi yang diperoleh seseorang karyawan yang datangnya dari rekan-rekan sekerja maupun atasan. Sedangkan untuk hubungan sebagai kelompok adalah seseorang karyawan akan berhubungan dengan banyak orang, baik secara individu maupun secara kelompok. Dalam hubungan ini ada beberapa yang perlu mendapatkan perhatian agar keberadaan kelompok ini menjadi lebih produktif, yaitu kepemimpinan yang baik, distribusi informasi yang baik, kondisi kerja yang baik dan sistem pengupahan yang jelas.

2. Tingkat kebisingan lingkungan kerja

Lingkungan kerja yang tidak tenang atau bising akan dapat menimbulkan pengaruh yang kurang baik yaitu adanya ketidaktenangan dalam bekerja. Bagi para karyawan tentu saja ketenangan lingkungan kerja sangat membantu dalam penyelesaian pekerjaan dan ini dapat meningkatkan produktivitas kerja.

3. Peraturan kerja

Peraturan kerja yang baik dan jelas dapat memberikan pengaruh yang baik terhadap kepuasan dan kinerja karyawan untuk pengembangan karir di perusahaan tersebut. Dengan perangkat peraturan tersebut karyawan akan dituntut untuk menjalankan aktivitasnya guna mencapai tujuan perusahaan maupun tujuan individu dengan pasti.

4. Penerangan

Dalam hal ini, penerangan bukanlah terbatas pada penerangan listrik, tetapi termasuk penerangan matahari. Hal ini sering kali karyawan memerlukan penerangan yang cukup apalagi pekerjaan yang dilakukan menuntut 
ketelitian. Untuk melaksanakan penghematan biaya maka dalam usaha penerangan hendaknya diusahakan dengan sinar matahari.

5. Sirkulasi udara

Sirkulasi atau pertukaran udara yang cukup maka pertama yangharus dilakukan pengadaan ventilasi. Ventilasi harus cukup besar terutama pada ruangan-ruangan yang dianggap terlalu panas.

6. Keamanan

Lingkungan kerja dengan rasa aman akan menimbulkan ketenangan dan kenyamanan, dimana hal ini akan dapat memberikan dorongan semangat untuk bekerja. Keamanan yang dimaksudkan ke dalam lingkungan kerja adalah keamanan terhadap milik pribadi karyawan. antara lain:

Menurut Soetjipto (2004) beberapa pengaruh atau dampak dari lingkungan kerja

1. Kenyamanan karyawan

Kenyamanan dalam bekerja biasanya akan berdampak pada kualitas kerja seseorang. Oleh karena itu, kenyamanan karyawan diterima dengan baik dalam artia lingkungan kerja mendukung, maka karyawan akan maksimal dalam bekerja.

2. Perilaku karyawan

Perilaku kerja adalah dimana orang-orang di tempat kerja dapat mengaktualisasikan dirinya melalui sikap dalam bekerja. Sikap yang diambil oleh karyawan untuk menentukan apa yang akan mereka lakukan di lingkungan tempat kerja mereka. Lingkungan kerja yang aman, nyaman, bersih, dan memiliki tingkat gangguan yang minimum sangat disukai oleh karyawan. Ketika karyawan mendapati tempat kerja yang kurang mendukung, perilaku karyawan saat di tempat kerja juga cenderung berubah. Misalnya dengan menurunnya kedisiplinan, tanggungjawab yang rendah, dan meningkatnya absensi.

3. Kinerja karyawan

Jika kondisi tempat kerja terjamin maka akan berdampak pada naiknya kinerja karyawan secara berkelanjutan. Kinerja karyawan menurun ketika perusahaan tidak memperhatikan fasilitas pendukung karyawannya dalam bekerja. Ketersediaan fasilitas dapat menyokong kinerja karyawan agar sslebih baik.

4. Tingkat stres karyawan

Lingkungan kerja yang tidak kondusif akan berpengaruh terhadap tingkat stres kerja karyawan. Ketika karyawan tidak dapat mengatasi stresnya dengan baik, bisa berakibat pada buruknya pelayanan karyawan.

\subsection{Pengaruh Antar Variabel}

1. Pengaruh Disiplin Kerja terhadap Kinerja Karyawan

Sutrisno (2012) mengemukakan pengertian disiplin adalah sikap kesediaan dan kerelaan seseorang untuk mematuhi dan menaati norma- norma peraturan yang berlaku di sekitarnya. Disiplin karyawan yang baik akan mempercepat tujuan perusahaan, sedangkan disiplin yang merosot akan menjadi penghalang dan memperlambat pencapaian tujuan perusahaan.

Menurut Setiyawan dan Waridin (2006) dan Aritonang (2005) menyatakan bahwa disiplin kerja pegawai bagian dari faktor kinerja.

Secara umum, disiplin menunjukan suatu kondisi atau sikap hormat yang ada pada diri karyawan terhadap peraturan dan ketetapan organisai. Kinerja 
organisasi akan tercapai apabila kinerja individu maupun kelompok dapat ditingkatkan.

Disiplin kerja pada karyawan sangat dibutuhkan, karena apa yang menjadi tujuan organisasi akan sukar dicapai apabila tidak ada disiplin kerja. Kedisplinan merupakan fungsi opratif manajemen sumber daya manusia terpenting, karena semakin baik disiplin pegawai, semakin tinggi prestasi kerja yang dicapainya. Tanpa disiplin karyawan yang baik, sulit bagi organisasi mencapai hasil yang optimal (Sedarmayanti, 207).

2. Pengaruh Lingkungan Kerja terhadap Kinerja Karyawan

Lingkungan kerja adalah segala sesuatu yang ada disekitar para pekerja yang dapat mempengaruhi dirinya dalam menjalankan tugas-tugas yang dibebankan. Misalnya kebersihan, musik dan lain-lain Nitisemito (2001:183).

Lingkungan kerja keadaan sekitar tempat kerja baik secara fisik maupun non fisik yang dapat memberikan kesan menyenangkan, mengamankan dan menentramkan. Kondisi lingkungan kerja yang baik akan membuat pegawai merasa nyaman dalam berkerja. Kenyamanan tersebut tentu akan berdampak pada peningkatan kinerja pegawai. Sebaliknya, ketidak nyamannan dari lingkungan kerja yang dialami oleh pegawai bisa berakibat fatal yaitu menurunnya kerja dari pegawai itu sendiri (Susilaningsih, 2013).

Lingkungan kerja menjadi bagian yang tak terpisahkan dalam aktivitas kerja seorang pegawai, baik berupa lingkingan kerja fisik maupun lingkungan kerja non fisik. Tempat kerja dimana seseorang mendedikasikan sepenuh tenaga dan pikirannya untuk menghasilkan sesuatu baik secara langsung akan berdampak pada proses kerjannya.

Lingkungan kerja merupakan salah satu faktor penting dalam menciptakan kinerja pegawai. Lingkungan kerja mempunyai pengaruh langsung terhadap karyawan didalam menyelesaikan pekerjaan yang pada akhirnya meningkatkan kinerja organisasi. Suatu kondisi lingkungan dikatakan baik apabila karyawan dapat melaksanakan kegiatan secara optimal, sehat, aman dan nyaman.

Penentuan dan penciptaan lingkungan kerja yang baik akan sangat menentukan keberhasilan pencapaian tujuan organisasi dan akan mampu memberikan sebuah pelayanan yang baik kepada masyarakat. Sebaliknya apabila lingkungan kerja yang tidak baik akan dapat menurunkan semangat kerja dan akhirnya dapat menurunkan kinerja pegawai

\subsection{Penelitian Terdahulu}

Penelitian terdahulu ini menjadi salah acuan peneliti dalam melakukan melakukan penelitian sehingga peneliti dapat memperkaya teori yang digunakan dalam mengkaji penelitian yang dilakukan. Dari penelitian terdahulu peneliti mengangkat beberapa penelitian sebagai refrensi dalam memperkaya bahan kajian pada penelitian. Berikut merupakan penelitian terdahulu berupa beberapa jurnal terkait terkait dengan penelitian yang peneliti lakukan. 
Tabel 2.1

Penlitian Terdahulu

\begin{tabular}{|c|c|c|c|}
\hline No. & Nama Peneliti & Judul & Hasil Penelitian \\
\hline 1 & Halim (2014) & $\begin{array}{l}\text { Pengaruh Kompensasi, } \\
\text { Disiplin Kerja dan } \\
\text { Motivasi Kerja } \\
\text { Terhadap Kinerja } \\
\text { Karyawan (Studi Kasus } \\
\text { pada Karyawan Bagian } \\
\text { Produksi PT. Sai } \\
\text { Apparel Industries) }\end{array}$ & $\begin{array}{l}\text { Menghasilkan analisis bahwa } \\
\text { ada pengaruh secara parsial } \\
\text { dan positif dari disiplin kerja } \\
\text { terhadap kinerja karyawan } \\
\text { secara signifikan. }\end{array}$ \\
\hline 2 & $\begin{array}{l}\text { Mulyadi dan } \\
\text { Marliana } \\
(2007)\end{array}$ & $\begin{array}{l}\text { Pengaruh Motivasi dan } \\
\text { Disiplin Kerja } \\
\text { Terhadap Kinerja } \\
\text { Karyawan pada } \\
\text { Departemen Weaving } \\
\text { PT. Adetex Cabang } \\
\text { Banjaran Kab. } \\
\text { Bandung" }\end{array}$ & $\begin{array}{l}\text { Menunjukkan terdapat } \\
\text { pengaruh yang signifikan dan } \\
\text { kuat dari disiplin kerja } \\
\text { terhadap kinerja karyawan. }\end{array}$ \\
\hline 3 & Arida (2012) & $\begin{array}{l}\text { Pengaruh Motivasi, } \\
\text { Lingkungan Kerja dan } \\
\text { Kepemimpinan } \\
\text { terhadap Kinerja } \\
\text { Karyawan PT. Sai } \\
\text { Apparel Semarang }\end{array}$ & $\begin{array}{l}\text { Menunjukkan variabel } \\
\text { lingkungan kerja berpengaruh } \\
\text { positif dan signifikan } \\
\text { terhadap kinerja karyawan. }\end{array}$ \\
\hline 4 & $\begin{array}{l}\text { Ahmad Taufik } \\
\text { Ismail (2013) }\end{array}$ & $\begin{array}{l}\text { Pengaruh Lingkungan } \\
\text { Kerja dan Karakteristik } \\
\text { Pekerjaan Terhadap } \\
\text { Kinerja Pegawai Pada } \\
\text { Dinas Perhubungan } \\
\text { Provinsi Sulawesi } \\
\text { Tenggara }\end{array}$ & $\begin{array}{l}\text { Hasil penelitian secara parsial } \\
\text { menunjukan bahwa: } \\
\text { (1) Lingkungan kerja } \\
\text { berpengaruh secara signifikan } \\
\text { terhadap kinerja pegawai. } \\
\text { (2) Karakteristik pekerjaan } \\
\text { berpengaruh signifikan } \\
\text { terhadap Kinerja Pegawai } \\
\text { Dinas Perhubungan Provinsi } \\
\text { Sulawesi Tenggara. }\end{array}$ \\
\hline 5 & Sarman (2012) & $\begin{array}{l}\text { Pengaruh Lingkungan } \\
\text { Kerja dan Motivasi } \\
\text { Kerja Terhadap Kinerja } \\
\text { Pegawai Pada Badan } \\
\text { Statistik (BPS) Kota } \\
\text { Kediri }\end{array}$ & $\begin{array}{l}\text { Hasil menunjukan bahwa } \\
\text { lingkungan kerja yang terdiri } \\
\text { dari lingkungan kerja fisik } \\
\text { dan lingkungan kerja non } \\
\text { fisik berpengaruh signifikan } \\
\text { terhadap kinerja pegawai } \\
\text { pada taraf kepercayaan } 95 \% \text {. }\end{array}$ \\
\hline
\end{tabular}




\subsection{Kerangka Analisis}

Sebagai gambaran penelitian, kerangka analisis dapat dilihat pada gambar sebagai berikut:

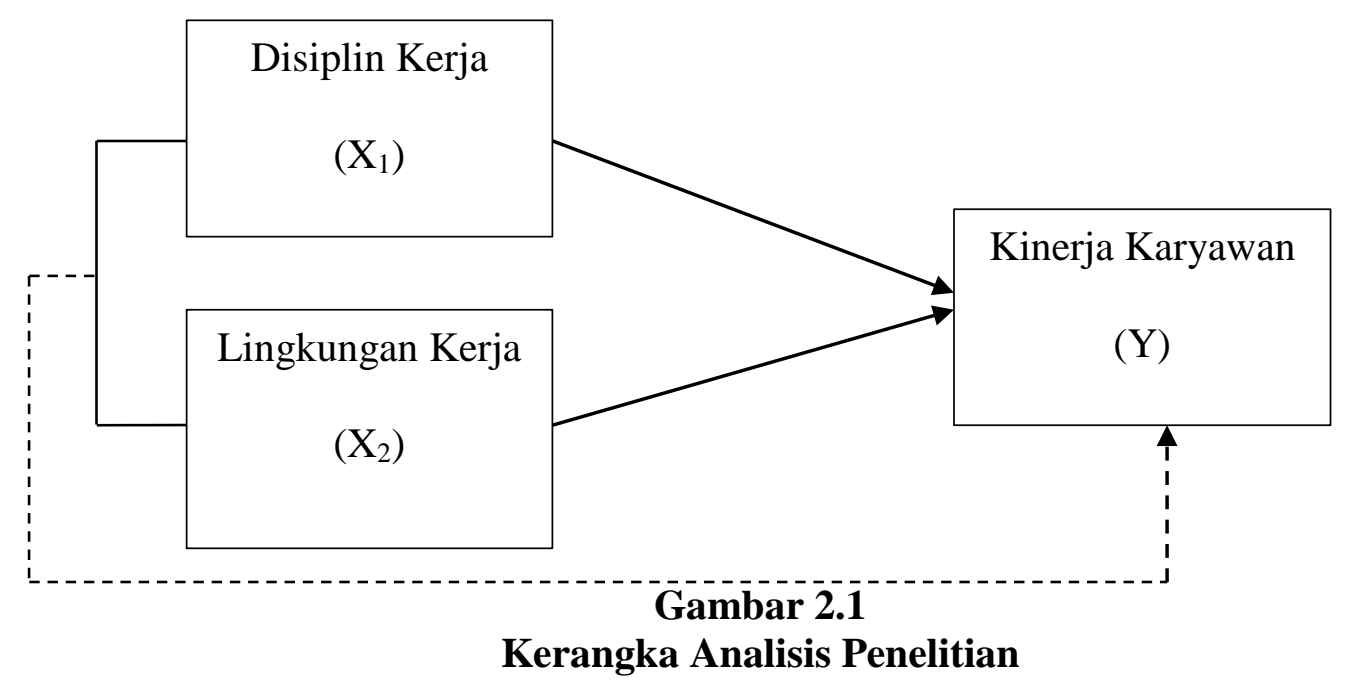

Keterangan:

1. Variable Independen, yaitu variable yang mempengaruhi variable yang lain. Variable Independen dalam penelitian ini adalah Disiplin Kerja $\left(\mathrm{X}_{1}\right)$ dan Lingkungan Kerja $\left(\mathrm{X}_{2}\right)$.

2. Variable Dependen, yaitu variable yang dipengaruhi oleh variable lain. Variabel Dependen dalam penelitian ini adalah Kinerja Karyawan (Y).

3. $\longrightarrow=$ Garis penghubung secara parsial.

4. $-\cdots+-\rightarrow=$ Garis penghubung secara simultan.

\subsection{Definisi Oprasional}

Table 2.2

Definisi Oprasional Variabel

\begin{tabular}{|c|c|c|c|}
\hline $\begin{array}{l}\text { Variabel } \\
\text { Penelitian }\end{array}$ & Definisi & Indikator & $\begin{array}{c}\text { Skala } \\
\text { Pengukuran }\end{array}$ \\
\hline Kinerja (Y) & $\begin{array}{l}\text { Kinerja karyawan adalah } \\
\text { hasil kerja secara kualitas } \\
\text { dan kuantitas yang } \\
\text { dicapai oleh seseorang } \\
\text { karyawan dalam } \\
\text { melaksanakan tugasnya } \\
\text { sesuai dengan tanggung } \\
\text { jawab yang diberikan }\end{array}$ & $\begin{array}{ll}\text { - } & \text { Ketepatan } \\
& \text { penyelesaian } \\
\text { tugas } \\
\text { - } & \text { Kesesuaian jam } \\
\text { kerja } \\
\text { - } & \text { Tingkat } \\
& \text { kehadiran } \\
\text { - } & \text { Kerjasama antar }\end{array}$ & Skala Ordinal \\
\hline
\end{tabular}




\begin{tabular}{|c|c|c|c|}
\hline & kepadanya & \begin{tabular}{l}
\multicolumn{1}{c}{ karyawan } \\
Menurut Setiawan \\
$(2014: 1477)$
\end{tabular} & \\
\hline $\begin{array}{c}\text { Disiplin } \\
\text { Kerja }\left(X_{1}\right)\end{array}$ & $\begin{array}{l}\text { Disiplin menunjukan } \\
\text { suatu kondisi atau sikap } \\
\text { hormat yang ada pada } \\
\text { diri karyawan terhadap } \\
\text { peraturan dan ketetapan } \\
\text { perusahaan. }\end{array}$ & 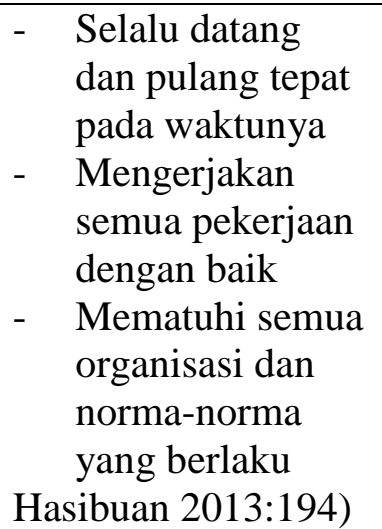 & Skala Ordinal \\
\hline $\begin{array}{c}\text { Lingkungan } \\
\text { Kerja }\left(\mathrm{X}_{2}\right)\end{array}$ & $\begin{array}{l}\text { Lingkungan kerja } \\
\text { adalah keseluruhan } \\
\text { sarana dan prasarana } \\
\text { kerja yang ada di sekitar } \\
\text { karyawan yang sedang } \\
\text { melakukan pekerjaan } \\
\text { yang dapat } \\
\text { mempengaruhi } \\
\text { pelaksanaan pekerjaan, } \\
\text { lingkungan kerja ini } \\
\text { meliputi tempat bekerja, } \\
\text { fasilitas, dan alat bantu } \\
\text { pekerjaan, kebersihan, } \\
\text { pencayahaan, } \\
\text { ketenangan, termasuk } \\
\text { juga hubungan kerja } \\
\text { antar karyawan. }\end{array}$ & $\begin{array}{ll}\text { - } & \text { Bangunan tempat } \\
& \text { kerja } \\
\text { - } & \text { Peralatan kerja } \\
& \text { yang memadai } \\
\text { - } & \text { Fasilitas } \\
\text { - } & \text { Tersedianya } \\
& \text { sarana angkutan } \\
\text { - } & \text { Hubungan rekan } \\
\text { kerja setingkat } \\
\text { - } \quad \text { Hubungan atasan } \\
\text { dengan karyawan } \\
\text { - } \quad \begin{array}{l}\text { Kerja sama antar } \\
\text { karyawan }\end{array} \\
\text { Siagan (2014:5961) }\end{array}$ & Skala Ordinal \\
\hline
\end{tabular}

\subsection{Hipotesis}

Sugiyono (2009) dan Asmawi, M. (2017) Hipotesis merupakan jawaban sementara terhadap rumusan masalah penelitian, dimana rumusan masalah penelitian telah dinyatakan dalam bentuk pertanyaan. Hipotesis dikatakan sementara karena jawaban yang diberikan baru didasarkan pada teori.

Hipotesis yang diajukan dalam penelitian ini adalah sebagai berikut:

1. H1: Diduga disiplin kerja berpengaruh terhadap kinerja karyawan pada The Madeline Hotel Bengkulu.

2. H2: Diduga lingkungan kerja berpengaruh terhadap kinerja karyawan pada The Madeline Hotel Bengkulu.

3. H3: Diduga disiplin kerja dan lingkungan kerja secara parsial dan simultan berpengaruh terhadap kinerja karyawan pada Pada The Madeline Hotel Bengkulu. 


\section{BAB III METODE PENELITIAN}

\subsection{Tempat dan Waktu Penelitian}

Tempat penelitian ini adalah di The Madeline Hotel Bengkulu Jl. Bakti Husada No. 88, Lingkar Barat, Gading Cempaka, Kota Bengkulu, Bengkulu 38211. Penelitian ini dilaksanakan pada 01 Juli sampai dengan 11 Juli 2019.

\subsection{Metode Penelitian}

Penelitian ini merupakan jenis penelitian dengan metode Deskriptif Kuantitatif, yaitu dimana penelitian membandingkan hasil pengumpulan data dan membuktikan dengan angka pada sejumlah populasi melalui sampel yang dianggap layak untuk diteliti. Dengan metode pendekatan surveyyaitu penelitian yang bertujuan untuk mendeskripsikan secarasistematis dan akurat suatu situasi atau area populasi tertentu yang bersifat factual. Penelitian dilakukan dengan pengamatan dan pemantauan secara langsung pada objek dengan menggunakan instrument berupa kuesioner.

Ditinjau dari antar hubungan variabelnya, penelitian ini adalah penelitian kasual sebab akbat, yaitu penelitian yang diadakan untuk menjelaskan hubungan antar variabel, variabel yang menyebabkan atau menentukan nilai variabel yang lain (Daniel dan Gates, 2001) unit analisis adalah individu Karena jawaban setiap responden mewakili pendapatnya sendiri.

\subsection{Populasi dan Sampel}

\subsubsection{Populasi}

Menurut Sugiyono (2010:117) populasi adalah wilayah generalisasi yang terdiri atas obyek/subyek yang mempunyai kualitas dan karakteristik tertentu yang ditetapkan oleh peneliti 
untuk dipelajari dan kemudian ditarik kesimpulannya. Jadi populasi bukan hanya orang, tetapi juga obyek dan benda-benda alam yang lain. Populasi juga bukan sekedar jumlah yang ada pada obyek/subyek yang dipelajari, tetapi meliputi seluruh karakteristik/sifat yang dimiliki oleh subyek atau obyek itu.

Dalam penelitian ini populasi yang digunakan adalah para karyawan The Madeline Hotel Bengkulu yang beralamat di Jl. Bakti Husada No. 88, Lingkar Barat, Gading Cempaka, Kota Bengkulu yang berjumlah 40 orang.

\subsubsection{Sampel}

Sampel merupakan bagian atau jumlah dan karakteritik yang dimiliki oleh populasi tersebut. Bila populasi besar, dan peneliti tidak mungkin mempelajari semua yang ada pada populasi, missal karena keterbatan dana, tenaga dan waktu, maka peneliti akan mengambil sampel dari populasi itu. Apa yang dipelajari dari sampel itu, kesimpulannya akan diberlakukan untuk populasi. Untuk itu sampel yang diambil dari populasi harus betul-betul representative (Sugiyono,2015).

Pengambilan sampel dilakukan dengan sampling jenuh, yang mana semua dari jumlah karyawan The Madeline Hotel Bengkulu dijadikan sebagai sampel, yaitu sebanyak 40 orang.

\subsection{Teknik Pengumpulan Data}

Menurut Sugiyono (2013:224) teknik pengumpulan data merupakan langkah yang paling strategis dalam penelitian, karena tujuan utama dari penelitian adalah mendapatkan data. Teknik pengumpulan data yang digunakan dalam penelitian ini adalah:

\subsubsection{Metode Observasi}

Menurut Arikunto (2010) observasi seringkali diartikan sebagai suatu aktiva yang sempit, yakni memperhatikan sesuatu dengan menggunakan mata. Didalam pengertian psikolok, observasi atau yang disebut juga pengamatan, meliputi pematan perhatian terhadap sesuatu objek dengan mengunakan seluruh alat indra.

\subsubsection{Metode Wawancara}

Wawancara adalah pengumpuan data primer yang diperoleh langsung dari hasil tanya jawab dengan informan. Esterbage dalam Sugiyono (2009:317) mengemukakan bahwa wawancara adalah pertemuan dua orang untuk bertukar informasi dan ide melalui tanya jawab sehingga dapat dikonstruksikan makna dalam suatu topik tertentu. Tujuan dari wawancara ini adalah untuk menemukan permasalahan secara lebih terbuka, dimana pihak yang diajak waancara yaitu alat perekam suara (voice recorder) dan beberapa alat tulis bila bila diperlukan untuk mencatat.

\subsubsection{Metode Kuesioner}

Menurut Kusumah (2011:78) kuesioner adalah daftar daftar pertanyaan tertulis yang diberikan kepada subjek yang ditelitih untuk mengumpulkan informasi yang dibutuhkan peneliti. Kuesioner ada dua macam yaitu kuesioner berstruktur atau bentuk tertutup dan kuesioner tidak berstruktur atau terbuka. Kuesioner tertutup berisikan pertanyaan yang disertai dengan pilihan jawaban.Kuesioner terbuka berisi pertanyaan yang tidak disertai dengan jawaban. 
Tabel 3.1

Bobot Kriteria Jawaban Skala Likert

\begin{tabular}{|c|c|c|}
\hline Keterangan & Angka & Arti \\
\hline SS & 5 & Sangat Setuju \\
\hline S & 4 & Setuju Ragu \\
\hline N & 3 & Netral \\
\hline TS & 2 & Tidak Setuju \\
\hline STS & 1 & Sangat tidak Setuju \\
\hline
\end{tabular}

Sumber: Hasil Penelitian, 2019

\subsection{Uji Instrumen}

Sebelum uji angket penelitian digunakan untuk penelitian yang sesungguhnya, angket penelitian ini diuji coba terlebih dahulu. Menurut Arikunto (2002) uji coba instrumen dilakukan untuk mengetahui apakah instrumen yang disusun berpengaruh pada besar tidaknya dan sangat menentukan bermutu tidaknya penelitian.

Menurut Onsardi (2018) Baik buruknya instrumen penelitian ditunjukkan oleh tingkat kesahihan (validity) dan keandalan (reliability). Uji coba instumen dimaksudkan untuk mengetahui validitas dan reliabilitas instrumen sehingga dapat diketahui layak tidaknya digunakan untuk pengumpulan data pada karyawan The Madeline Hotel Bengkulu.Responden yang digunakan dalam penelitian ini adalah karyawan The Madeline Hotel Bengkulu.

\subsubsection{Uji Validitas}

Pada uji validitas instrumen yang akan dilakukan pada setiap instrumen penelitian memperoleh hasil jika $r$ positif, serta $r \geq 0,30$ maka pernyataan tersebut valid, dan jika $r<0,30$ maka item pernyataan tidak valid (Sugiyono 2013). Dapat dilihat pada tabel 3.2

Tabel 3.2

\section{Hasil Uji Validitas}

\begin{tabular}{|c|c|c|c|c|}
\hline \multirow{3}{*}{ Variabel } & $\begin{array}{c}\text { Item } \\
\text { Pernyataan }\end{array}$ & $\begin{array}{c}\text { Corrected Item } \\
\text { Pernyataan Total } \\
\text { Correlation }\end{array}$ & $\mathrm{R}$ & Keterangan \\
\hline \multirow{3}{*}{ Disiplin Kerja } & 1 & 0.644 & 0.30 & Valid \\
\cline { 2 - 5 } & 2 & 0.727 & 0.30 & Valid \\
\cline { 2 - 5 } & 3 & 0.579 & 0.30 & Valid \\
\hline \multirow{3}{*}{$\begin{array}{c}\text { Lingkungan } \\
\text { Kerja }\end{array}$} & 1 & 0.695 & 0.30 & Valid \\
\cline { 2 - 5 } & 2 & 0.460 & 0.30 & Valid \\
\cline { 2 - 5 } & 3 & 0.488 & 0.30 & Valid \\
\cline { 2 - 5 } & 5 & 0.564 & 0.30 & Valid \\
\cline { 2 - 5 } & 6 & 0.429 & 0.30 & Valid \\
\cline { 2 - 5 } & 7 & 0.624 & 0.30 & Valid \\
\hline Kinerja & 1 & 0.729 & 0.30 & Valid \\
\hline
\end{tabular}




\begin{tabular}{|l|l|l|l|l|}
\hline Karyawan & 2 & 0.641 & 0.30 & Valid \\
\cline { 2 - 5 } & 3 & 0.495 & 0.30 & Valid \\
\cline { 2 - 5 } & 4 & 0.451 & 0.30 & Valid \\
\hline
\end{tabular}

Sumber: Output SPSS 24.0

Dari tabel di atas dilihat bahwa nilai Corrected Item Pernyataan Total Correlation masing-masing item mempunyai nilai $>r_{\text {tabel }}(0,30)$. Hal ini menunjukan bahwa item pernyataan dari masing-masing variabel valid dan layak digunakan dalam penelitian ini. Item pernyataan yang valid berarti mampu untuk mengukur dan menjelaskan variabel-variabel yang diteliti secara jelas dan tepat.

\subsubsection{Uji Reliabilitas}

Pada uji reliabilitas yang dilakukan terhadap setiap instrumen penelitian memperoleh hasil bahwa nilai Cronbach's Alpha pada setiap instrumen penelitian ini menunjukan nilai > 0,30 menunjukkan reliabel sempurna (Agus Tri Basuki dan Nano Prawoto 2016). Hal tersebut menunjukan bahwa semua instrumen penelitian ini reliabel sehingga dapat digunakan untuk melakukan penelitian. Berikut ini hasil dari uji reliabilitas sebagaimana disajikan pada tabel 3.3

Tabel 3.3

\section{Hasil Uji Reliabilitas}

\begin{tabular}{|c|l|c|c|}
\hline No & \multicolumn{1}{|c|}{ Variabel } & Cronbach's Alpha & Keterangan \\
\hline 1 & Disiplin Kerja & 0,855 & Reliabel \\
\hline 2 & Lingkungan Kerja & 0,751 & Reliabel \\
\hline 3 & Kinerja Karyawan & 0,796 & Reliabel \\
\hline
\end{tabular}

Sumber: Output SPSS 24,0

Hasil estimasi reliabilitas dengan menggunakan formula Cronbach's Alpha untuk instrumen variabel Disiplin Kerja, Lingkungan Kerja dan Kinerja Karyawan sebesar 0,855; 0,751; 0,796. Dengan demikian ketiga instrument tersebut reliable. Semua telah memenuhi sebagai instrumen yang reliable, sehingga bisa digunakan untuk mengumpulkan data.

\subsection{Teknik Analisis Data}

Agar mendapatkan hasil penelitian yang sesuai dengan tujuan penelitian, maka diperlukan metode analisis data yang benar. Pengujian dilakukan dengan menggunakan bantuan software Statistical Package for Social Sciences (SPSS) 24,0. Adapun teknik analisis data dalam penelitian ini sebagai berikut:

\subsubsection{Analisis Statistik Deskriptif}

Statistik deskriptif digunakan untuk menganalisis dan menyajikan data kuantitatif dengan tujuan untuk mengetahui gambaran perusahaan yang dijadikan sampel penelitian. Pada bagian ini peneliti akan menganalisa data tersebut satu persatu yang didasarkan pada jawaban responden yang dihimpun berdasarkan koesioner yang telah diisi oleh responden selama penelitian berlangsung. Adapun berdasarkan kreteria yang dipakai pada katagori jawaban responden, maka untuk lebih memudakan digunakan 3 katagori, yaitu: tinggi, sedang dan rendah. Cara pengkatagorian data berdasarkan rumus dari Azwar (2009:108) adalah sebagai berikut: 

a. Tinggi
$: \mathrm{X} \geq+\mathrm{SD}$
b. Sedang
$: \mathrm{M}-\mathrm{SD} \leq \mathrm{X}<\mathrm{M}+\mathrm{SD}$
c. Rendah
$: \mathrm{X}<\mathrm{M}-\mathrm{SD}$

\subsubsection{Uji Asumsi Klasik}

Ada beberapa pengujian yang harus dijalankan terlebih dahulu untuk menguji apakah model yang dipergunakan tersebut mewakili atau mendekati kenyataan yang ada.Untuk menguji kelayakan model regresi yang digunakan, maka harus terlebih dahulu memenuhi uji asumsi klasik. Terdapat empat jenis pengujian pada uji asumsi klasik ini, diantaranya:

\subsubsection{Uji Normalitas}

Uji normalitas digunakan untuk menguji apakah distribusi variabel terikat untuk setiap nilai variabel bebas tertentu berditribusi normal atau tidak. Dalam model regresi linier, asumsi ini ditunjukkan oleh nilai error yang berdistribusi normal. Model regresi yang baik adalah model regresi yang memiliki distribusi normal atau mendekati normal, sehingga layak dilakukan pengujian secara statistik. Pengujian normalitas data menggunakan Test of Normality Kolmogorov-Smirnov dalam program SPSS 24,0.

Dasar pengambilan keputusan bisa dilakukan berdasarkan probabilitas (Asymtotic Significance), yaitu:

1. Jika probabilitas $>0,05$ maka distribusi dari model regresi adalah normal.

2. Jika probabilitas $<0,05$ maka distribusi dari model regresi adalah tidak normal.

\subsubsection{Uji Multikolinieritas}

Uji multikolinieritas bertujuan untuk menguji apakah pada sebuah model regresi ditemukan adanya korelasi antar variabel independen. Jika terjadi korelasi, maka dinamakan terdapat problem multikolinieritas. Model regresi yang baik seharusnya tidak terjadi korelasi di antara variabel independen. Jika terbukti ada multikolinieritas, sebaiknya salah satu dari variabel independen yang ada dikeluarkan dari model, lalu pembuatan model regresi diulang kembali (Singgih Santoso, 2012:234).

Untuk mendeteksi ada tidaknya multikolinieritas dapat dilihat pada besaran Variance Inflation Factor (VIF) dan Tolerance. Pedoman suatu model regresi yang bebas multikolinieritas adalah mempunyai angka tolerance mendekati 1 . Batas VIF adalah 10, jika nilai VIF di bawah 10, maka tidak terjadi gejala multikolinieritas (Gujarati, 2012:432). Menurut Singgih Santoso (2012:236) rumus yang digunakan adalah sebagai berikut:

$$
\mathrm{VIF}=\frac{1}{\text { Tolerance }} \text { atau Tolerance }=\frac{1}{V I F}
$$

\subsubsection{Uji Heteroskedastisitas}

Situasi heteroskedastis akan menyebabkan penaksiran koefisien-koefisien regresi menjadi tidak efisien dan hasil taksiran dapat menjadi kurang atau melebihi dari yang semestinya. Dengan demikian, agar koefisien-koefisien regresi tidak menyesatkan, maka situasi heteroskedastis tersebut harus dihilangkan dari model regresi.

Menurut Gujarati (2012:406) untuk menguji ada tidaknya heteroskedastisitas digunakan uji rank-Spearman yaitu dengan mengkorelasikan variabel independen terhadap nilai absolut dari residual hasil regresi. Jika nilai koefisien korelasi antara variabel independen dengan nilai 
absolut dari residual signifikan, maka kesimpulannya terdapat heteroskedastisitas (varian dari residual tidak homogen).

\subsubsection{Analisis Regresi Linier Berganda}

Analisis kuantitatif dengan menggunakan alat analisis linier berganda adalah suatu analisis yang digunakan oleh peneliti,bila peneliti bermaksud meramalkan bagaimana keadaann (naik turunnya) variabel dependen, apabila dua variabel atau lebih variabel sebagai faktor indikator, sebagaimana dikutip dari Sugiyono, 2013:192. Persamaan regresi linier tersebut adalah sebagai berikut:

$$
\mathrm{Y}=\mathrm{a}+\mathrm{b}_{1} \mathrm{X}_{1}+\mathrm{b}_{2} \mathrm{X}_{2}+\mathrm{ei}
$$

Dimana:

Y $\quad=$ Variabel dependen (kinerja karyawan)

a $\quad=$ Konstanta

$b_{1}-b_{2}=$ Variabel Independen (disiplin kerja dan lingkungan kerja)

ei $\quad=$ Error

Namun untuk memudahkan analisis regresi linier berganda maka peneliti menggunakan program SPSS 24.0 dalam pengolahan data.

\subsubsection{Analisis Korelasi Ganda}

Menurut Sugiyono (2014) korelasi ganda (Multiple correlation) merupakan angka yang menunjukan arah dan kuatnya hubungan antara dua variabel secara bersama-sama atau lebih dengan variabel yang lain. Ukuran yang dipakai untuk mengetahui kuat atau tidaknya hubungan antara $\mathrm{x}$ dan y disebutkan Koefisien Korelasi (r). Nilai koefisien korelasi harus terdapat dalam batas $-1<\mathrm{r}<1$, dimana:

1. Bila nilai $r=-1$, maka korelasi kedua variabel dikatakan sangat kuat dan negative artinya sifat hubungan dari kedua variabel berlawanan arah, maksudnya jika nilai $\mathrm{X}$ naik maka nilai Y akan turun atau sebaliknya.

2. Bila nilai $r=0$ atau mendekati 0 , maka korelasi dari kedua variabel sangat lemah atau tidak terdapat korelasi sama sekali.

3. Bila nilai $\mathrm{r}=1$ atau mendekati 1 maka korelasi dari kedua variabel sangat kuat dan positif, artinya hubungan dari kedua variabel yang diteliti bersifat searah, maksudnya juka nilai X naik maka nilai Y juga naik atau sebaliknya.

\section{Tabel 3.4}

Pedoman Untuk Memberikan Interprestasi Terhadap Koefisien Korelasi

\begin{tabular}{|c|c|}
\hline Interval Koefisien & Tingkat Hubungan \\
\hline $0,00-0,199$ & Sangat rendah \\
\hline $0,20-0,399$ & Rendah \\
\hline $0,40-0-599$ & Cukup Kuat \\
\hline $0,60-0,799$ & Kuat \\
\hline $0,80-1,000$ & Sangat Kuat \\
\hline
\end{tabular}

Sumber (Sugiyono, 2011:231) 
3.6.5 Koefisien Determinasi $\left(\mathbf{R}^{2}\right)$

Koefisien determinasi $\left(\mathrm{R}^{2}\right)$ intinya mengukur seberapa jauh kemampuan model dalam menerangkan variasi variabel dependen, Nilai koefisien determinasi adalah antara nol dan satu. Nilai $\mathrm{R}^{2}$ yang kecil berarti kemampuan variabel- variabel independen dalam menjelaskan variasi variabel dependen amat terbatas. Nilai yang mendekati satu berarti variabel-variabel independen memberikan hampir semua informasi yang dibutuhkan untuk memprediksi variasi variabel dependen. Secara umum koefisien determinasi untuk data silang (crossection) relatif rendah karena adanya variasi yang besar antara masing-masing pengamatan, sedangkan untuk data runtun waktu (time series) biasanya mempunyai nilai koeefisien determinan tinggi (Ghozali, 2011:97).

\subsection{Uji Hipotesis}

Uji Hipotesis dilakukan untuk mengetahui hipotesis yang diajukan bermakna atau tidak maka digunakan perhitungan pengujian signifikansi dengan menggunakan uji $f$ dan $t$. Uji Hipotesis pada penelitian ini adalah menguji hubungan langsung atau tidak langsung antara variable disiplin kerja $\left(\mathrm{X}_{1}\right)$ dan lingkungan kerja $\left(\mathrm{X}_{2}\right)$ terhadap kinerja karyawan $(\mathrm{Y})$ pada The Madeline Hotel Bengkulu. Adapun proses pengujiannya adalah sebagai berikut:

\subsubsection{Uji t}

Untuk menguji variabel yang berpengaruh antara Disiplin Kerja $\left(\mathrm{X}_{1}\right)$ dan Lingkungan Kerja $\left(\mathrm{X}_{2}\right)$ terhadap Kinerja $(\mathrm{Y})$ karyawan pada The Madeline Hotel Bengkulu secara individual (parsial) maka digunakan uji t, Ghozali (2009). Adapun kriteria pengujian uji t adalah sebagai berikut :

1. Jika $\alpha<0,05$ maka hipotesis diterima berarti ada pengaruh signifikan variabel independen (variabel bebas) secara parsial terhadap variabel dependen (variabel terikat).

2. Jika $\alpha>0,05$ maka hipotesisditolak berarti tidak ada pengaruh signifikan variabel independen (variabel bebas) secara parsial terhadap variabel dependen (variable terikat).

\subsubsection{Uji F}

Pengujian variabel yang berpengaruh antara Disiplin Kerja $\left(X_{1}\right)$ dan Lingkungan Kerja $\left(\mathrm{X}_{2}\right)$ terhadap Kinerja $(\mathrm{Y})$ karyawan pada The Madeline Hotel Bengkulu secara bersama-sama (simultan) maka digunakan uji $\mathrm{F}$.

Adapun kriteria pengujian uji F adalah sebagai berikut, Ghozali (2009):

1. Jika Sig < 0,05 maka hipotesis diterima berarti ada pengaruh signifikan variabel independen secara simultan terhadap variabel dependen.

2. Jika Sig > 0,05 maka hipotesis ditolak berarti tidak ada pengaruh signifikan variabel independen secara simultan terhadap variabel dependen. 


\section{BAB IV \\ HASIL DAN PEMBAHASAN}

\subsection{Sejarah The Madeline Hotel Bengkulu}

Pertama kali The Madeline Hotel Bengkulu didirikan pada tahun 1998 dan gedung selesai pembangunannya pada tahun 2000 gedung pertama yang dibangun yaitu penerimaan tamu, kamar tamu mulai dari nomor 101 sampai 105, ada juga kamar 201 sampai 203, kamar 207 sampai 210 kamar 211 sampai 219 dan juga sebuah gedung restoran yang dibangun pada tahun yang sama yaitu yang bernama mutiara room. Sewaktu itu The Madeline Hotel Bengkulu masih dimiliki oleh bapak Agus Salim dan juga dia masih menjabat kapolda Bengkulu.

Seiring berjalannya waktu setelah pensiun The MadelineHotel Bengkulu pindah tangan atau dijual oleh bapak Agus Salim kepada pemilik Hotel Splash yang bernama Yuan Degama dibeli pada awal tahun 2013, setelah resmi The Hotel Madeline Hotel Bengkulu pindah tangan kepemilikan, mulailah hotel tersebut direnovasi dan penambahan gedung bar, gedung pertama yang dibangun yaitu gedung restoran yang bernama Pandan Resto yang dibangun pada tahun 2013, gedung berikutnya yang dibangun pada awal tahun 2014 yang bernama Mutiara Room. Pada tahun 2016 ada penambahan kolam renang yang dibangun awal bulan januari dan selesai pembangunan sampai bulan april 2016, ada pula penambahan fasilitas hotel yaitu mini bus dan mobil Avanza untuk mengantar dan menjemput tamu serta untuk mengantar karyawan yang tidak memiliki kendaraan.

\subsection{Analisis Deskriptif}

Responden yang menjadi subjek pada penelitian ini adalah semua karyawan yang bekerja pada The Medeline Hotel Bengkulu. Dari hasil pengunpulan data melalui koesioner terhadap 40 orang yang dijadikan responden dalam penelitian ini, maka dapat diketahui karakteristik responden berdasarkan jenis kelamin, usia, pendidikan terakhir dan lama berkerja.

\subsubsection{Karakteristik Responden Berdasarkan Jenis Kelamin}

Jumlah responden berdasarkan jenis kelamin yang ada pada The Medeline Hotel Bengkulu dapat dilihat pada tabel 4.1

\section{Tabel 4.1}

\section{Karakteristik Responden Berdasarkan jenis Kelamin}

\begin{tabular}{|c|c|c|}
\hline Jenis Kelamin & Frekuensi & Persentase \\
\hline Laki-laki & 25 & $62.5 \%$ \\
\hline Perempuan & 15 & $37.5 \%$ \\
\hline Total & 40 & $100 \%$ \\
\hline
\end{tabular}

Sumber: Data yang diolah 2019

Berdasarkan tabel di atas diketahui karakteristik responden berdasarakan jenis kelamin laki-laki sebanyak 25 orang responden atau 62.5\%. Dari data tersebut menyatakan bahwa karyawan The Medeline Hotel Bengkulu lebih banyak laki-laki dari perempuan.

\subsubsection{Karakteristik Responden Berdasarkan Usia}

Jumlah responden berdasarkan usia yang ada pada The Medeline Hotel Bengkulu dapat dilihat pada tabel 4.2 
Tabel 4.2

Karakteristik Responden Berdasarkan Usia

\begin{tabular}{|l|c|c|}
\hline \multicolumn{1}{|c|}{ Usia } & Frekuensi & Persentase \\
\hline 20-25 Tahun & 15 & $37.5 \%$ \\
\hline 26-29 Tahun & 20 & $50 \%$ \\
\hline 30> Tahun & 5 & $12.5 \%$ \\
\hline Total & 40 & $100 \%$ \\
\hline
\end{tabular}

Sumber: Data yang diolah 2019

Berdasarkan tabel 4.2 diketahui karakteristik responden berdasarkan usia yang paling mendominasi yaitu usia 26-29 tahun dengan persentase 50\%. Dari data tersebut menyatakan bahwa The Medeline Hotel Bengkulu yang paling banyak yaitu umur 26-29 tahun karena diumur tersebut dalam mendirikan suatu usaha sudah memiliki pengalaman yang lebih banyak, dan usahanya sudah lama berdiri.

\subsubsection{Karakteristik Responden Berdasarkan Pendidikan Terakhir}

Jumlah responden berdasarkan pendidikan terakhir yang ada pada The Medeline Hotel Bengkulu dapat dilihat pada tabel 4.3

Tabel 4.3

\section{Karakteristik Responden Berdasarkan Pendidikan Terakhir}

\begin{tabular}{|l|c|c|}
\hline \multicolumn{1}{|c|}{ Pendidikan Terakhir } & Frekuensi & Persentase \\
\hline SLTA & 20 & $50.0 \%$ \\
\hline Diploma 3 & 15 & $37.5 \%$ \\
\hline Strata (S1) & 3 & $7.5 \%$ \\
\hline Lain-Lain & 2 & $5 \%$ \\
\hline Total & 40 & $100 \%$ \\
\hline
\end{tabular}

Sumber: Data yang diolah 2019

Berdasarkan tabel 4.3 diketahui karakteristik responden berdasarkan pendidikan terakhir yang paling mendominasi SLTA sebanyak 20 responden dengan persentase $50.0 \%$. Dari data tersebut dapat disimpulkan bahwa The Medeline Hotel Bengkulu sudah memiliki pendidikan yang cukup tinggi.

\subsubsection{Karakteristik Responden Berdasarkan Lama bekerja}

Jumlah responden berdasarkan lama bekerja yang ada pada The Medeline Hotel Bengkulu dapat dilihat pada tabel 4.4

Tabel 4.4

Karakteristik Responden Berdasarkan Lama Berkerja

\begin{tabular}{|l|c|c|}
\hline \multicolumn{1}{|c|}{ Lama Berkerja } & Frekuensi & Persentase \\
\hline 1-3 Tahun & 7 & $17.5 \%$ \\
\hline 3-5 Tahun & 20 & $50 \%$ \\
\hline 5> Tahun & 13 & $32.5 \%$ \\
\hline Total & 40 & 100.0 \\
\hline
\end{tabular}

Sumber: Data yang diolah 2018 
Berdasarkan tabel 4.4 diketahui karakteristik responden berdasarkan lama bekerja yang paling mendominasi yaitu 3-5 tahun sebanyak 20 responden dengan persentase 50\%. Dari data tersebut dapat disimpulkan bahwa karyawan The Medeline Hotel Bengkulu loyal terhadap perkerjaannya.

\subsection{Deskripsi Tanggapan Responden Terhadap Variabel Penelitian}

4.3.1 Tanggapan Responden Terhadap Variabel Kinerja Karyawan (Y)

Pada variabel Kinerja Karyawan penilaian dilakukan dengan empat indikator, yaitu (1) Ketepatan penyelesaian tugas, (2) Kesesuaian jam kerja, (3) Tingkat kehadiran, (4) Kerjasama antar karyawan. Adapun tanggapan responden terhadap variabel Kinerja Karyawan dapat dilihat pada tabel 4.5

Table 4.5

Tanggapan Responden

Terhadap Variabel Kinerja Karyawan (Y)

\begin{tabular}{|c|c|c|c|c|c|c|c|c|}
\hline \multirow{2}{*}{ No } & \multirow{2}{*}{ Pernyataan } & \multicolumn{5}{|c|}{ Peniliaian } & \multirow{2}{*}{ Jumlah } & \multirow{2}{*}{$\begin{array}{c}\text { Rata- } \\
\text { rata }\end{array}$} \\
\hline & & STS & TS & $\mathrm{N}$ & $\mathrm{S}$ & SS & & \\
\hline 1 & $\begin{array}{l}\text { Pekerjaan yang saya } \\
\text { lakukan sesuai dengan } \\
\text { standar kerja }\end{array}$ & & 3 & 14 & 18 & 5 & 145 & 3.62 \\
\hline 2 & $\begin{array}{l}\text { Pekerjaan yang saya } \\
\text { lakukan tepat waktu }\end{array}$ & & 1 & 14 & 18 & 7 & 151 & 3.77 \\
\hline 3 & $\begin{array}{l}\text { Pekerjaan yang saya } \\
\text { lakukan akurat }\end{array}$ & 1 & 1 & 15 & 14 & 9 & 149 & 3.72 \\
\hline 4 & $\begin{array}{l}\text { Saya mampu } \\
\text { memahami tugas-tugas } \\
\text { yang berkaitan dengan } \\
\text { pekerjaan }\end{array}$ & & 2 & 17 & 13 & 8 & 153 & 3.82 \\
\hline Rata & rata & & & & & & & 3.73 \\
\hline
\end{tabular}

Sumber: Data yang diolah 2019

Adapun hasil analisis penilaian responden pada tabel 4.5 terhadap variabel Kinerja Karyawan (Y) (saya mampu memahami tugas-tugas yang berkaitan dengan pekerjaan) memiliki rata-rata tertinggi yaitu 3.82, dan memiliki rata-rata terendah yaitu 3.62. Dengan variabel Kinerja Karyawan menghasilkan nilai rata-rata sebesar 3.73. Menunjukan bahwa rata-rata pernyataan penilaian responden mengenai variabel Kinerja Karyawan adalah pada kategori baik.

\subsubsection{Tanggapan Responden Terhadap Variabel Disiplin Kerja $\left(X_{1}\right)$}

Pada variabel Disiplin Kerja penilaian dilakukan dengan tiga Indikator, yaitu(1) Selalu datang dan pulang tepat pada waktunya, (2) Mengerjakan semua pekerjaan dengan baik, (3) Mematuhi semua organisasi dan norma-norma yang berlaku. Adapun tanggapan responden terhadap variabel Disiplin Kerja dapat dilihat pada tebel 4.6 
Table 4.6

Tanggapan Responden

Terhadap Variabel Disiplin Kerja $\left(\mathbf{X}_{1}\right)$

\begin{tabular}{|c|c|c|c|c|c|c|c|c|}
\hline \multirow{2}{*}{ No } & \multirow{2}{*}{ Pernyataan } & \multicolumn{5}{|c|}{ Penilaian } & \multirow{2}{*}{ Jumlah } & \multirow{2}{*}{$\begin{array}{l}\text { Rata } \\
\text {-rata }\end{array}$} \\
\hline & & STS & TS & $\mathrm{N}$ & $\mathrm{S}$ & SS & & \\
\hline 1 & $\begin{array}{l}\text { Saya datang ke tempat kerja } \\
\text { tepat pada waktunya dan } \\
\text { saya pulang kerja sesuai } \\
\text { dengan waktu yang telah } \\
\text { ditentukan }\end{array}$ & & & 15 & 18 & 7 & 152 & 3.80 \\
\hline 2 & $\begin{array}{l}\text { Saya bekerja sesuai } \\
\text { prosedur kerja yang telah } \\
\text { ditetapkan }\end{array}$ & 1 & 1 & 15 & 13 & 10 & 150 & 3.75 \\
\hline 3 & $\begin{array}{l}\text { Saya mematuhi semua } \\
\text { peraturan dan norma-norma } \\
\text { yang berlaku di perusahaan }\end{array}$ & 1 & 2 & 18 & 16 & 3 & 138 & 3.45 \\
\hline $\mathrm{Ra}$ & rata & & & & & & & 3.66 \\
\hline
\end{tabular}

Sumber: Data yang diolah 2018

Adapun hasil analisis penilaian responden pada tabel 4.6 terhadap variabel Disiplin Kerja $\left(\mathrm{X}_{1}\right)$ (Saya datang ke tempat kerja tepat pada waktunya dan saya pulang kerja sesuai dengan waktu yang telah ditentukan) memiliki nilai rata-rata tertinggi yaitu 3.80 dan memiliki rata-rata terendah yaitu 3,45. Variabel Disiplin Kerja menghasilkan nilai rata-rata sebesar 3.66. Menunjukan bahwa rata-rata pernyataan penilaian responden mengenai variabel Disiplin Kerja adalah pada kategori baik.

\subsubsection{Tanggapan Responden Terhadap Variabel Lingkungan Kerja $\left(X_{2}\right)$}

Pada variabel Lingkungan Kerja penilaian dilakukan dengan tujuh Indikator, yaitu (1) Bangunan tempat kerja, (2) Peralatan kerja yang memadai, (3) Fasilitas, (4) Tersedianya sarana angkutan, (5) Hubungan rekan kerja setingkat, (6) Hubungan atasan dengan bawahan, (7) Kerja sama antar karyawan. Adapun tanggapan responden terhadap variabel Disiplin Kerja pada tabel 4.7

Table 4.7

Tanggapan Responden Terhadap Variabel Lingkungan Kerja $\left(\mathrm{X}_{2}\right)$

\begin{tabular}{|c|l|c|c|c|c|c|c|c|}
\hline No & \multicolumn{1}{|c|}{ Pernyataan } & \multicolumn{5}{c|}{ Peniliaian } & \multirow{2}{*}{ Jumlah } & $\begin{array}{c}\text { Rata } \\
\text {-rata }\end{array}$ \\
\cline { 3 - 9 } & & STS & TS & N & S & SS & & \\
\hline 2 & $\begin{array}{l}\text { Saya merasa nyaman dengan } \\
\text { bangunan di tempat kerja }\end{array}$ & & & 21 & 15 & 4 & 143 & 3.57 \\
\hline 2 & $\begin{array}{l}\text { Peralatan yang memadai } \\
\text { sangat membantu saya dalam } \\
\text { menyelesaikan tugas }\end{array}$ & $\begin{array}{l}\text { Fasilitas perusahaan sangat } \\
\text { dibutuhkan sebagai } \\
\text { pendukung dalam }\end{array}$ & 2 & 14 & 18 & 6 & 148 & 3.70 \\
\hline
\end{tabular}




\begin{tabular}{|c|c|c|c|c|c|c|c|}
\hline & $\begin{array}{l}\text { menyelesaikan pekerjaan } \\
\text { yang saya lakukan }\end{array}$ & & & & & & \\
\hline 4 & $\begin{array}{l}\text { Tersedianya sarana angkutan } \\
\text { umum maupun yang } \\
\text { disediakan dari perusahaan } \\
\text { sangat membantu saya untuk } \\
\text { sampai di tempat kerja } \\
\text { dengan tepat waktu }\end{array}$ & & 13 & 21 & 6 & 153 & 3.82 \\
\hline 5 & $\begin{array}{l}\text { Saya dan rekan kerja } \\
\text { setingkat dapat menciptakan } \\
\text { hubungan yang harmonis dan } \\
\text { kekeluargaan }\end{array}$ & 2 & 12 & 18 & 8 & 152 & 3.80 \\
\hline 6 & $\begin{array}{l}\text { Saya dan atasan saling } \\
\text { menghargai dan menghormati } \\
\text { antara satu sama lain }\end{array}$ & & 13 & 21 & 6 & 153 & 3.82 \\
\hline 7 & $\begin{array}{l}\text { Saya selalu menjalin kerja } \\
\text { sama yang baik dengan rekan } \\
\text { kerja saya }\end{array}$ & 1 & 10 & 20 & 9 & 161 & 4.01 \\
\hline \multicolumn{7}{|c|}{ Rata-rata } & 3.78 \\
\hline
\end{tabular}

Sumber: Data yang diolah 2019

Adapun hasil analisis penilaian responden pada tabel 4.7 terhadap variabel Lingkungan Kerja $\left(\mathrm{X}_{1}\right)$ (Saya selalu menjalin kerja sama yang baik dengan rekan kerja saya) dengan rata-rata tertinggi yaitu 4,01 dan indikator Lingkungan Kerja memiliki rata-rata terendah yaitu 3,57. Variabel Lingkungan Kerja menghasilkan nilai rata-rata sebesar 3.78 Menunjukan bahwa ratarata pernyataan penilaian responden mengenai variabel Lingkungan Kerja adalah pada kategori baik.

\subsection{Hasil Uji Asumsi Klasik} 4.4.1 Uji Normalitas

Pada tabel uji normalitas dengan mengunakan kolmogorov-smirnov nilai sig $>0,05$ bisa dilihat bahwa data berdistribusi normal seperti pada tabel 4.8 


\section{Gambar 4.1}

\section{Hasil Uji Normalitas}

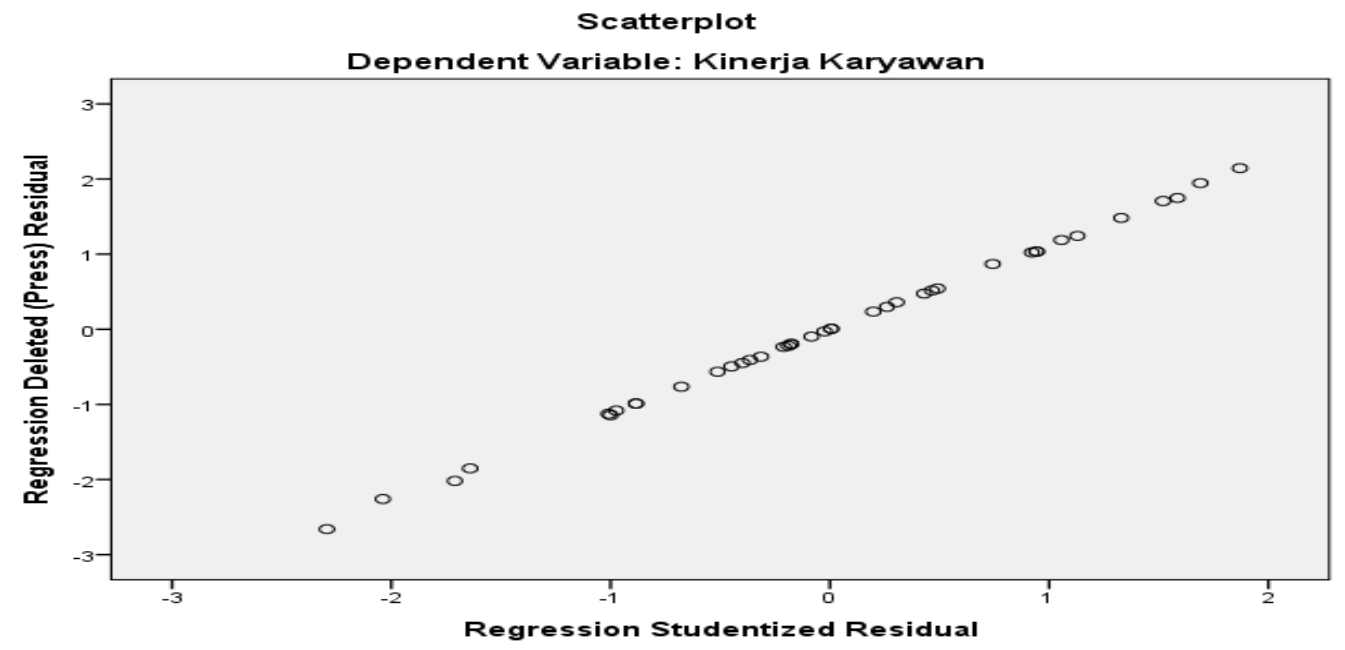

Sumber: Output SPSS 24,0

Grafik di atas menunjukan bahwa grafik uji normalitas mengambarkan penyebaran data di sekitar garis diagonal dan penyebarannya mengikuti arah garis diagonal grafik tersebut, maka model regresi yang digunakan dalam penelitian ini memenuhi asumsi normalitas.

\section{Tabel 4.8}

\section{Hasil Uji Normalitas}

\begin{tabular}{|l|r|r|r|r|r|r|}
\hline & \multicolumn{3}{|c|}{ Kolmogorov-Smirnov $^{\mathrm{a}}$} & \multicolumn{3}{c|}{ Shapiro-Wilk } \\
\cline { 2 - 7 } & Statistic & Df & \multicolumn{1}{c|}{ Sig. } & Statistic & Df & Sig. \\
\hline $\begin{array}{l}\text { Unstandardized } \\
\text { Residual }\end{array}$ & .093 & 40 & .000 & .985 & 40 & .000 \\
\hline
\end{tabular}

Sumber: Output SPSS 24,0

Dari hasil uji normalitas diketahui nilai statistik 0,093 atau nilai (sig $a=0,072>0,05$ ), dapat disimpulkan bahwa residual menyebar normal.

\subsubsection{Hasil Uji Multikolinearitas}

Uji multikolinearitas ini bertujuan untuk mengetahui apakah tiap-tiap variabel bebas yaitu Disiplin Kerja dan Lingkungan Kerja berhubungan secara linear. Pengujian adanya multikolinearitas ini dapat dilakukan dengan melihat nilai toleransi diatas 0,1 dan VIF nya lebih kecil dari 10 tidak ada kecenderungan terjadi gejala multikolinear. Pengujian multikoloneeritas mengunakan software SPSS versi 24 dapat dilihat pada tabel 4.9 
Tabel 4.9

Hasil Uji Multikolinearitas

\begin{tabular}{|c|l|c|c|c|}
\hline No & \multicolumn{1}{|c|}{ Variabel } & Tolerance & VIF & Keterangan \\
\hline 1 & Disiplin Kerja & 0.533 & 1.878 & Non Multikolinearitas \\
\hline 2 & Lingkungan Kerja & 0.533 & 1.878 & Non Multikolinearitas \\
\hline 3 & Kinerja Karyawan & 0.533 & 1.878 & Non Multikolinearitas \\
\hline
\end{tabular}

Sumber: Output SPSS 24,0

Berdasarkan tabel 4.9 di atas terlihat bahwa semua variabel mempunyai nilai toleransi di atas 0,1 dan nilai VIF dibawah 10, dengan demikian dapat disimpulkan bahwa variabel pada penelitian ini bebas multikolinearitas.

\subsubsection{Hasil Uji Heteroskedastisitas}

Uji heterokedasitas bertujuan untuk menguji apakah dalam model regresi terjadi ketidak sama varians. Adapun hasil uji statistic heteroskedastisitas yang diperoleh dalam penelitian ini sebagaimana disajikan pada tabel 4.10

Tabel 4.10

Hasil Uji Heteroskedastisitas

\begin{tabular}{|c|c|c|c|c|c|c|}
\hline \multicolumn{7}{|c|}{ Coefficients $^{\mathrm{a}}$} \\
\hline \multirow{2}{*}{\multicolumn{2}{|c|}{ Model }} & \multicolumn{2}{|c|}{$\begin{array}{l}\text { Unstandardized } \\
\text { Coefficients }\end{array}$} & \multirow{2}{*}{$\begin{array}{l}\text { Standardized } \\
\text { Coefficients } \\
\text { Beta }\end{array}$} & \multirow[b]{2}{*}{$\mathrm{T}$} & \multirow[b]{2}{*}{ Sig. } \\
\hline & & $\mathrm{B}$ & Std. Error & & & \\
\hline 1 & (Constant) & 4.650 & 1.588 & & 2.928 & .007 \\
\hline & Disiplin Kerja & .357 & .139 & .397 & 2.566 & .016 \\
\hline & Lingkungan Kerja & .472 & .179 & .555 & 2.637 & .014 \\
\hline & Kinerja Karyawan & .723 & .182 & .642 & 3.973 & .001 \\
\hline
\end{tabular}

Sumber: Output SPSS 24,0

Dari tabel Coefficients yang ditampilkan untuk uji heterokesdastisitas menampakan output regresi Residual dengan variabel-variabel independent seperti terlihat pada tabel di atas, outputnya menunjukkan tidak adanya hubungan yang signifikan antara seluruh variabel independent terhadap nilai absolute residual, sehingga dapat disimpulkan bahwa asumsi nonheteroskedastisitas.

\subsection{Hasil Penelitian}

\subsubsection{Analisis Regresi Linear Berganda}

Analisis regresi linear berganda yang akan dibahas dalam penelitian ini sehingga peneliti bisa menggambarkan mengenai tanggapan responden (Disiplin Kerja dan Lingkungan Kerja) terhadap Kinerja Karyawan pada The Medeline Hotel Bengkulu. Berdasarkan estemasi regresi linier berganda dengan menggunakan program SPSS Versi 24,0 For Windows, maka dapat dilihat pada tabel 4.11 
Tabel 4.11

Hasil Analisis Regresi Linear Berganda

\begin{tabular}{|c|c|c|c|c|c|c|}
\hline \multicolumn{7}{|c|}{ Coefficients $^{\mathrm{a}}$} \\
\hline \multirow{2}{*}{\multicolumn{2}{|c|}{ Model }} & \multicolumn{2}{|c|}{$\begin{array}{c}\text { Unstandardized } \\
\text { Coefficients }\end{array}$} & $\begin{array}{l}\text { Standardized } \\
\text { Coefficients }\end{array}$ & \multirow[b]{2}{*}{$\mathrm{t}$} & \multirow[b]{2}{*}{ Sig. } \\
\hline & & B & Std. Error & Beta & & \\
\hline \multirow[t]{3}{*}{1} & $($ Constant $)$ & .980 & 1.397 & & .701 & .487 \\
\hline & $\begin{array}{l}\text { Disiplin } \\
\text { Kerja }\end{array}$ & .484 & .137 & .410 & 3.545 & .001 \\
\hline & $\begin{array}{l}\text { Lingkungan } \\
\text { Kerja }\end{array}$ & .322 & .071 & .524 & .4 .528 & .000 \\
\hline
\end{tabular}

Sumber: Output SPSS 24,0

Dari perhitungan hasil di atas didapatkan persamaan regresinya adalah sebagai berikut :

$\mathrm{Y}=0.980+0,484\left(\mathrm{X}_{1}\right)+0,322\left(\mathrm{X}_{2}\right)$

Berdasarkan persamaan regresi di atas, maka dapat dijelaskan sebagai berikut:

1. Nilai Konstanta 0.980 mempunyai arti bahwa apabila variabel Disiplin Kerja $\left(\mathrm{X}_{1}\right)$, Lingkungan Kerja $\left(\mathrm{X}_{2}\right)$ terhadap Kinerja Karyawan (Y) sama dengan nol, maka variabel Kinerja Karyawan akan tetap yaitu 0.980 apabila variabel Disiplin Kerja $\left(\mathrm{X}_{1}\right)$ dan Lingkungan Kerja $\left(\mathrm{X}_{2}\right)$ sama dengan nol.

2. Koefisien Regresi $X_{1}$, sebesar 0.484 mempunyai makna jika nilai variabel Disiplin Kerja $\left(\mathrm{X}_{1}\right)$ naik satu satuan maka nilai Kinerja Karyawan $(\mathrm{Y})$ akan naik sebesar 0.484 dengan asumsi variabel Lingkungan Kerja $\left(\mathrm{X}_{2}\right)$ dianggap tetap.

3. Koefisien Regresi $X_{2}$, sebesar 0.322 mempunyai makna jika nilai variabel Lingkungan Kerja $\left(\mathrm{X}_{2}\right)$ naik satu satuan maka nilai variabel Kinerja Karyawan(Y) akan naik sebesar 0.322 dengan asumsi variabel Disiplin Kerja $\left(\mathrm{X}_{1}\right)$ dianggap tetap.

\subsubsection{Analisis Korelasi Parsial $\left(\mathrm{X}_{1}-\mathrm{Y}\right)$}

Hasil nilai korelasi parsial hubungan antara variabel independent Disiplin Kerja X_1 terhadap variabel dependent Y dapat dilihat pada tabel 4.12

Tabel 4.12

Hasil Nilai Korelasi Parsial $\left(\mathrm{X}_{1}-\mathrm{Y}\right)$

\begin{tabular}{|l|l|r|r|}
\hline \multicolumn{3}{|c|}{ Correlations } \\
\hline \multirow{2}{*}{ Disiplin Kerja } & Pearson Correlation & Disiplin Kerja & Kinerja Karyawan \\
& Sig. (2-tailed) & 1 & $.865^{* *}$ \\
\cline { 2 - 4 } & N & & .000 \\
\cline { 2 - 4 } & & 40 & 40 \\
\hline Kinerja Karyawan & Pearson Correlation & $.865^{* *}$ & 1 \\
\hline
\end{tabular}




\begin{tabular}{|l|l|r|r|}
\hline & Sig. (2-tailed) & .000 & \\
\cline { 2 - 4 } & $\mathrm{N}$ & 40 & 40 \\
\hline \multirow{2}{*}{$* *$. Correlation is significant at the 0.01 level (2-tailed). }
\end{tabular}

Sumber :Output SPSS 24,0

Berdasarkan tabel di atas diperoleh nilai (R) produk moment sebesar 0,865 yang berarti korelasi parsial hubungan antara variabel independent Disiplin Kerja X_1 terhadap variabel dependent $Y$ termasuk kategori Tinggi.

\subsubsection{Analisis Korelasi Parsial $\left(X_{2}-Y\right)$}

Hasil nilai korelasi parsial hubungan antara variabel independent lingkungan kerja X_2 terhadap variabel dependent (Y) dapat dilihat pada tabel 4.13

Tabel 4.13

Hasil Nilai Korelasi Parsial $\left(\mathrm{X}_{2}-\mathrm{Y}\right)$

\begin{tabular}{|l|l|r|r|}
\hline \multicolumn{2}{|c|}{} & Kinerja Karyawan & \multicolumn{1}{c|}{$\begin{array}{c}\text { Lingkungan } \\
\text { Kerja }\end{array}$} \\
\hline Lingkungan Kerja & $\begin{array}{l}\text { Pearson } \\
\text { Correlation }\end{array}$ & 1 & $.766^{* *}$ \\
\cline { 2 - 4 } & Sig. (2-tailed) & & .000 \\
\cline { 2 - 4 } & $\mathrm{N}$ & 40 & 40 \\
\hline \multirow{5}{*}{ Kenerja Karyawan } & $\begin{array}{l}\text { Pearson } \\
\text { Correlation }\end{array}$ & $.766^{* *}$ & 1 \\
\cline { 2 - 4 } & Sig. (2-tailed) & .000 & \\
\cline { 2 - 4 } & $\mathrm{N}$ & 40 & \\
\hline \multirow{2}{*}{$* *$. Correlation is significant at the 0.01 level (2-tailed). } & \\
\hline
\end{tabular}

Sumber: Output SPSS 24,0

Berdasarkan tabel di atas diperoleh nilai $(\mathrm{R})$ produk moment sebesar 0,766 yang berarti korelasi parsial hubungan antara variabel independent Lingkungan Kerja $\mathrm{X}_{2}$ terhadap variabel dependent (Y) termasuk kategori rendah.

\subsubsection{Koefisisen Determinasi $\left(R^{2}\right)$}

Untuk mengetahui besarnya presentase sumbangan pengaruh variabel bebas Disiplin Kerja $\left(\mathrm{X}_{1}\right)$ dan Lingkungan Kerja $\left(\mathrm{X}_{2}\right)$ terhadap variabel terikat Kinerja Karyawan $(\mathrm{Y})$ maka dari perhitungan komputer menggunakan SPSS 24,0 didapatkan uji koefisien determinasi sebagaimana disajikan pada tabel 4.14

\section{Tabel 4.14}

\section{Nilai Koefisien Determinasi $\left(\mathbf{R}^{2}\right)$}

\begin{tabular}{|l|r|r|r|r|}
\hline \multicolumn{5}{|c|}{ Model Summary $^{\mathrm{b}}$} \\
\hline Model & $\mathrm{R}$ & R Square & Adjusted R Square & $\begin{array}{c}\text { Std. Error of the } \\
\text { Estimate }\end{array}$ \\
\hline 1 & $.865^{\mathrm{a}}$ & .748 & .735 & \multicolumn{1}{c|}{1.05727} \\
\hline
\end{tabular}

a. Predictors: (Constant), Lingkungan Kerja, Disiplin Kerja

b. Dependent Variable: Kinerja Karyawan

Sumber: Output SPSS 24,0 
Berdasarkan tabel di atas dapat diketahui nilai koefisien determinasi Adjusted $\left(\mathrm{R}^{2}\right)$ diperoleh nilai sebesar 0.748 (Agus Tri Basuki dan Nano Prawoto, 2016:51). Nilai ini mempunyai arti bahwa variabel Disiplin Kerja dan Lingkungan Kerja terhadap variabel Kinerja Karyawan memberikan sumbangan sebesar 0.735 atau $73.5 \%$ terhadap Kinerja Karyawan pada The Medeline Hotel Bengkulu sedangkan sisanya sebesar 26.5\% dipengaruhi oleh variabel lain yang tidak masuk dalam model penelitian ini.

\subsubsection{Pengujian Hipotesis Dengan Uji t}

Untuk menguji pengaruh variabel bebas secara parsial terhadap variabel terikat digunakan uji t sebagaimana disajikan pada tabel 4.15

Tabel 4.15

Hasil Pengujian Hipotesis dengan Uji t

\begin{tabular}{|c|c|c|c|c|c|c|}
\hline \multicolumn{7}{|c|}{ Coefficients $^{\mathrm{a}}$} \\
\hline \multirow{2}{*}{\multicolumn{2}{|c|}{ Model }} & \multicolumn{2}{|c|}{$\begin{array}{l}\text { Unstandardized } \\
\text { Coefficients }\end{array}$} & \multirow{2}{*}{$\begin{array}{c}\text { Standardized } \\
\text { Coefficients } \\
\text { Beta }\end{array}$} & \multirow[b]{2}{*}{$\mathrm{t}$} & \multirow[b]{2}{*}{ Sig. } \\
\hline & & B & $\begin{array}{l}\text { Std. } \\
\text { Error }\end{array}$ & & & \\
\hline \multirow[t]{3}{*}{1} & (Constant) & .980 & 1.397 & & .701 & .487 \\
\hline & Disiplin Kerja & .484 & .137 & .410 & 3.545 & .001 \\
\hline & $\begin{array}{l}\text { Lingkungan } \\
\text { Kerja }\end{array}$ & .322 & .071 & .524 & $\begin{array}{r}.4 .52 \\
8\end{array}$ & .000 \\
\hline & t Variable. & Kary & & & & \\
\hline
\end{tabular}

Sumber: Output SPSS 24.0

Melalui perhitungan yang dilakukan dengan menggunakan program SPSS, maka perbandingan antara $t_{\text {hit }}$ dengan $t_{a / 2}(n-k-1)=40-2-1=37(2,985)$ setiap variabel sebagai berikut:

1. Disiplin Kerja yaitu $t_{\text {hit }}>t_{\alpha / 2}(3.545>2,026)$ dan $(\operatorname{sig} \alpha=0,001<0,05)$, hal tersebut menyatakan bahwa adanya pengaruh Disiplin Kerja $\left(\mathrm{X}_{1}\right)$ terhadap Kinerja Karyawan secara signifikan pada The Medeline Hotel Bengkulu.

2. Berdasarkan uji $t_{h i t}$ untuk variabel Lingkungan Kerja $\left(X_{2}\right)$ yaitu $t_{h i t}>t_{\alpha / 2}(4.528>$ 2.026) dan ( $\operatorname{sig} \alpha=0,000<0,05$ ), hal tersebut menyatakan bahwaadanya pengaruh Lingkungan Kerja terhadap Kinerja Karyawan secara signifikan pada The Medeline Hotel Bengkulu.

\subsubsection{Pengujian Hipotesis Dengan Uji F}

Untuk menguji pengaruh variabel bebas secara parsial terhadap variabel terikat digunakan uji $\mathrm{F}$ sebagaimana dapat dilihat pada tabel 4.16 
Tabel 4.16

Hasil Pengujian Hipotesis dengan Uji F

\begin{tabular}{|l|l|r|r|r|r|r|}
\hline \multicolumn{7}{|l|}{ ANOVA $^{\mathrm{a}}$} \\
\hline \multirow{2}{*}{ Model } & $\begin{array}{c}\text { Sum of } \\
\text { Squares }\end{array}$ & Df & Mean Square & F & Sig. \\
\hline 1 & Regression & 121.045 & 2 & 60.522 & 51.651 & $.000^{\mathrm{b}}$ \\
\cline { 2 - 7 } & Residual & 43.355 & 37 & 1.172 & & \\
\cline { 2 - 7 } & Total & 164 & 39 & & & \\
\hline \multicolumn{7}{|l|}{ a. Dependent Variable: Kinerja Karyawan } \\
\hline
\end{tabular}

Sumber: Output SPSS 24,0

Berdasarkan tabel uji hipotesis dengan uji $\mathrm{F}$ diatas diperoleh $\mathrm{F}_{\text {hitung }}$ sebesar 51.651. dengan nilai $\mathrm{F}_{\text {tabel }}$ sebesar 1.97 yaitu $(51.651>1.97)$ dan $(\operatorname{sig} \alpha=0.000<0,05)$, maka dengan demikian dapat disimpulkan bahwa $\mathrm{H}_{3}$ diterima artinya secara simultan variabel Disiplin Kerja dan Lingkungan Kerja berpengaruh signifikan terhadap Kinerja Karyawan pada The Medeline Hotel Bengkulu.

\subsection{Pembahasan Hasil Penelitian}

Berdasarkan hasil penelitian dan pengolahan data mentah yang dilakukan pada The Medeline Hotel Bengkulu melalui penyebaran kuesoner terhadap 40 orang responden yang telah diuji sehingga dapat diketahui pengaruh Disiplin Kerja dan Lingkungan Kerja Terhadap Kinerja Karyawan pada The Medeline Hotel Bengkulu.

1. Pengaruh Disiplin Kerja $\left(\mathrm{X}_{1}\right)$ Terhadap Kinerja Karyawan $(\mathrm{Y})$

Hasil penelitian menunjukan bahwa variabel Disiplin Kerja berpengaruh positif dan signifikan terhadap kinerja karyawan di The Madeline Hotel Bengkulu. Hal ini terlihat pada uji t yang menyatakan memiliki nilai 3.545 , maka $\mathrm{H}_{1}$ dalam penelitian ini diterima.

Indikator saya mematuhi semua peraturan dan norma-norma yang berlaku di perusahaan memiliki skor terendah, yaitu sebesar $(3,45)$. Hal ini menunjukan bahwa ketaatan pada standar kerja merupakan hal yang kurang dimiliki oleh sebagian karyawan The Madeline Hotel Bengkulu. Sebagai contoh bahwa karyawan masih sering mengabaikan tugas yang menjadi kewajibannya, seperti keterlambatan dalam memenuhi keinginan para tamu. Hal ini terlihat bahwa karyawan kurang dapat mematuhi standar kerja yang telah ditetapkan.

Menurut Malayu Hasibuan (2012:193), kedisiplinan adalah kesadaran dan kesediaan seseorang menaati semua peraturan perusahaan dan norma-norma sosial yang berlaku. Hal tersebut dapat mendorong timbulnya peningkatan kinerja serta tercapainya tujuan perusahaan. Tingkat kedisiplinan karyawan The Madeline Hotel Bengkulu yang tinggi dan baik akan berpengaruh terhadap pencapaian target-target yang telah ditetapkan oleh perusahaan. Ketika karyawan The Madeline Hotel Bengkulu memiliki kesadaran dan kedisiplinan yang tinggi, maka tidak akan terjadi 
keterlambatan penanganan tugas yang harus diselesaikan. Hal ini menunjukkan bahwa kinerja karyawan dapat ditingkatkan dengan disiplin kerja yang tinggi.

Dari penjelasan tersebut dapat disimpulkan bahwa adanya disiplin kerja karyawan The Madeline Hotel Bengkulu yang baik maka akan menghasilkan kinerja karyawan yang baik, sebaliknya apabila disiplin kerja karyawan The Madeline Hotel Bengkulu kurang baik akan menghasilkan kinerja karyawan yang kurang baik pula. Penelitian ini juga didukung dengan penelitian yang dilakukan oleh Priyo (2014) yang menunjukkan bahwa disiplin kerja berpengaruh positif dan signifikan terhadap kinerja karyawan.

2. Pengaruh Disiplin Kerja $\left(\mathrm{X}_{2}\right)$ Terhadap Kinerja Karyawan (Y)

Hasil penelitian menunjukkan bahwa variabel lingkungan kerja berpengaruh positif dan signifikan terhadap kinerja karyawan The Madeline Hotel Bengkulu. Hal ini terlihat pada uji $\mathrm{t}$ yang menyatakan memiliki nilai 4.528, maka $\mathrm{H}_{2}$ dalam penelitian ini dapat diterima.

Skor terendah ditunjukkan pada indikator saya merasa nyaman dengan bangunan di tempat kerja , yaitu sebesar (3,57). Berdasarkan hasil penelitian diketahui bahwa kurangnya fasilitas yang memadai membuat karyawan sulit dalam melakukan pekerjaan.

Menurut Suprihatiningrum (2012) lingkungan kerja merupakan salah satu faktor yang memengaruhi kinerja seorang karyawan. Lingkungan kerja yang baik, fasilitas yang memadai, dan tempat kerja yang kondusif serta hubungan yang baik dengan rekan kerja maupun atasan akan memberikan rasa nayaman kepada para karyawan. Saat karyawan merasa nyaman dan adanya dukungan dari lingkungan sosialnya maka karyawan akan terdorong untuk bekerja dengan baik. Ketika karyawan The Madeline Hotel Bengkulu bekerja di lingkungan kerja yang nyaman dan kondusif serta hubungan di antara sesama karyawan pun baik, maka karyawan akan cenderung bekerja lebih baik. Hal ini menunjukkan bahwa kinerja karyawan dapat ditingkatkan dengan lingkungan kerja yang baik.

Dari penjelasan tersebut dapat disimpulkan bahwa adanya lingkungan kerja yang baik maka akan menghasilkan kinerja karyawan yang baik, sebaliknya apabila lingkungan kerja kurang baik akan menghasilkan kinerja karyawan yang kurang baik pula. Penelitian ini juga didukung dengan penelitian yang dilakukan oleh Kusmayadi (2014) yang menunjukkan bahwa lingkungan kerja berpengaruh positif dan signifikan terhadap kinerja karyawan.

3. Pengaruh Disiplin Kerja dan Lingkungan Kerja Terhadap Kinerja karyawan

Hasil penelitian menunjukkan bahwa variabel lingkungan kerja dan disiplin kerja secara bersama-sama berpengaruh positif terhadap kinerja karyawan. Hal ini terlihat pada uji $\mathrm{F}$ yang menyatakan nilai $\mathrm{F}_{\text {hitung }}$ yaitu 51.651, maka dengan demikian dapat disimpulkan bahwa $\mathrm{H}_{3}$ diterima artinya secara bersamaan variabel Disiplin Kerja $\left(\mathrm{X}_{1}\right)$ dan Lingkungan Kerja $\left(\mathrm{X}_{2}\right)$ memiliki pengaruh yang signifikan terhadap Kinerja Karyawan (Y) pada The Medeline Hotel Bengkulu.

Lingkungan kerja dan disiplin kerja sama-sama memiliki pengaruh yang positif terhadap kinerja karyawan. Lingkungan kerja yang kurang nyaman dan tidak kondusif serta tingkat disiplin karyawan yang rendah menyebabkan target yang telah ditetapkan oleh perusahaan tidak dapat tercapai sebagaimana yang diharapkan. Hal ini 
dikarenakan karyawan cenderung malas bekerja di lingkungan yang kurang nyaman dan merasa tidak terkontrol dengan disiplin yang rendah sehingga beberapa target yang telah ditetapkan tidak tercapai. Karyawan akan lebih giat dalam bekerja di lingkungan kerja dan disiplin kerja yang lebih baik untuk meningkatkan kinerjanya. Hal ini mengindikasikan bahwa lingkungan kerja dan disiplin kerja berdampak atau menimbulkan pengaruh terhadap menurunnya kinerja karyawan di The Madeline Hotel Bengkulu.

Lingkungan kerja yang baik dan kondusif sangat berpengaruh terhadap kinerja karyawan, terbukti dari hasil penelitian yang menunjukkan adanya pengaruh yang positif dan signifikan antara lingkungan kerja terhadap kinerja karyawan. Selain itu tingkat kedisiplinan karyawan yang tinggi juga berpengaruh terhadap kinerja karyawan, terbukti dari hasil penelitian yang menunjukkan adanya pengaruh positif dan signifikan antara disiplin kerja terhadap kinerja karyawan. Hal ini berarti jika lingkungan kerja baik dan tingkat kedisiplinan karyawan tinggi maka akan meningkatkan kinerja karyawan, begitu juga sebaliknya.

Lingkungan kerja di The Madeline Hotel Bengkulu kurang kondusif karena kurang penyediaan fasilitas kerja yang memadai akan apabila fasilitas telah dilengkapi maka akan meningkatkan kenyamanan, ketenangan dan suasana kerja yang kondusif di The Madeline Hotel Bengkulu. Selain itu hubungan antar karyawan juga perlu diperhatikan untuk menghindari hal-hal yang tidak diinginkan seperti kecemburuan sosial, konflik di tempat kerja, dan hubungan yang kurang harmonis lainnya. Diharapkan dengan perlakuan seperti itu akan mendorong karyawan untuk bekerja lebih baik lagi sehingga kinerjanya lebih optimal.

Disiplin kerja yang diterapkan oleh The Madeline Hotel Bengkulu masih belum maksimal karena belum menggunakan standar yang baik sehingga karyawan cenderung melakukan tindakan indisipliner. Ketidakdisiplinan yang dilakukan karyawan The Madeline Hotel Bengkulu menjadikan target-target yang telah ditetapkan oleh perusahaan tidak dapat tercapai secara optimal. Mulai dari terjadinya keterlambatan karyawan dalam menangani tugas hingga penyelesainnya. Hal ini mengindikasikan belum optimalnya kinerja karyawan The Madeline Hotel Bengkulu yang dipengaruhi oleh faktor disiplin kerja.

Lingkungan kerja yang baik dan kondusif cenderung memberikan rasa nyaman kepada karyawan sehingga mereka akan terdorong untuk bekerja dengan baik pula. Karyawan yang terdorong untuk bekerja dengan baik di perusahaan maka akan berdampak pada peningkatan kinerja karyawan pula. Meskipun demikian, tingkat disiplin yang rendah akan memicu tindakan indisipliner dari karyawan sehingga karyawan akan bekerja sesuka hati mereka tanpa mempedulikan target-target yang telah ditetapkan oleh perusahaan. Lingkungan kerja yang baik tanpa didukung disiplin kerja yang baik maka akan cenderung menghasilkan kinerja yang kurang maksimal.

Lingkungan kerja yang buruk dan tidak mendukung di tempat bekerja kerap kali menimbulkan masalah terutama kurang nyamannya karyawan dalam bekerja. Kurang nyamannya karyawan dalam bekerja cenderung akan menurunkan keinginan karyawan untuk bekerja sehingga akan berdampak pada penurunan kinerja karyawan. Namun demikian, tingkat disiplin karyawan yang baik akan membantu karyawan mencapai target-target yang telah ditetapkanoleh perusahaan. Karyawan dengan tingkat disiplin yang tinggi kerap menghasilkan kinerja yang baik dan tinggi pula. 
Artinya, tingkat disiplin yang tinggi tanpa di dukung oleh lingkungan kerja yang baik belum mampu meningkatkan kinerja karyawan di perusahaan sehingga perlu adanya dukungan antara keduanya.

Dari penjelasan di atas dapat disimpulkan bahwa pada lingkungan kerja yang baik didukung dengan tingkat kedisiplinan yang tinggi akan menghasilkan kinerja karyawan yang baik, sebaliknya pada lingkungan kerja kurang baik dan tingkat kedisiplinan yang rendah akan menghasilkan kinerja karyawan yang kurang baik pula. Penelitian ini juga didukung dengan penelitian yang dilakukan oleh Kusmayadi (2014) yang menunjukkan bahwa lingkungan kerja berpengaruh positif dan signifikan terhadap kinerja karyawan. 


\section{BAB V \\ KESIMPULAN DAN SARAN}

\subsection{Kesimpulan}

Berdasarkan hasil penelitian yang telah dilakukan tentang pengaruh Disiplin Kerja dan Lingkungan Kerja Terhadap Kinerja Karyawanpada The Medeline Hotel Bengkulu, dapat disimpulkan sebagai berikut:

1. Disiplin Kerja $\left(\mathrm{X}_{1}\right)$ berpengaruh positif dan signifikan terhadap Kinerja Karyawan (Y) pada Medeline Hotel, hal ini dibuktikan dengan hasil uji t menunjukan nilai $t_{\text {hit }}>t_{\alpha / 2}(3.545>2.026)$ dan $(\operatorname{sig} \alpha=0,003<0,050)$. Ini berarti $\mathrm{H}_{0}$ ditolak dan $\mathrm{H}_{\mathrm{a}}$ diterima.

2. Lingkungan Kerja $\left(\mathrm{X}_{2}\right)$ berpengaruh positif dan signifikan terhadap Kinerja Karyawan (Y) pada The Medeline Hotel Bengkulu, hal ini dibuktikan dengan hasil uji $\mathrm{t}$ menunjukan nilai $\mathrm{t}_{\text {hit }}>\mathrm{t}_{\alpha / 2}(4.528>2.026)$ dan $(\operatorname{sig} \alpha=0,003<0,05)$. Ini berarti $\mathrm{H}_{0}$ ditolak dan $\mathrm{H}_{\mathrm{a}}$ diterima.

3. Disiplin Kerja $\left(\mathrm{X}_{1}\right)$ dan Lingkungan Kerja $\left(\mathrm{X}_{2}\right)$ secara bersama-sama berpengaruh secara positif dan signifikan terhadap Kinerja Karyawan (Y) pada The Medeline Hotel Bengkulu, hal ini dibuktikan dengan uji $\mathrm{F}$ menunjukkan nilai $\mathrm{F}_{\text {hitung }}>\mathrm{F}_{\text {tabel }}$, yaitu $(5.1651>2.026)$ dan $(\operatorname{sig}$ á $=0.000<0,05)$. Ini berarti $\mathrm{H}_{0}$ ditolak dan $\mathrm{H}_{\mathrm{a}}$ diterima.

4. Berdasarkan uji koefisien korelasi didapat nilai $\mathrm{R}=0,865$ dan koefisien determinasi $\mathrm{R}^{2}=0,748$ nilai mempunyai makna bahwa Disiplin Kerja $\left(\mathrm{X}_{1}\right)$ dan Lingkungan Kerja $\left(\mathrm{X}_{2}\right)$ memberikan kontribusi pengaruh sebesar 0,735 atau 73.5 terhadap Kinerja Karyawan (Y) pada The Medeline Hotel Bengkulu sedangkan sisanya sebesar 26.5 dipengaruhi oleh variabel-variabel lain yang tidak termasuk dalam penelitian ini.

\subsection{Saran}

Berdasarkan hasil penelitian, pembahasan dan kesimpulan yang diperoleh, maka saran yang dapat diberikan sebagai berikut:

1. Hasil penelitian menunjukan adanya pengaruh antara variabel Disiplin Kerja $\left(\mathrm{X}_{1}\right)$ dan Lingkungan Kerja $\left(\mathrm{X}_{2}\right)$ terhadap Kinerja Karyawan (Y) Pada The Medeline Hotel Bengkulu, variabel Lingkungan Kerja memiliki rata-rata terendah yaitu 3.57 disarankan untuk lebih baiknya perlu ditingkatkan lagi Disiplin Kerja, seperti perbanyak motivasi dalam bekerja serta memberikan penerapan contoh yang baik sehingga dapat meningkatan Disiplin Kerja seperti pemberian insentif, jaminan Disiplin Kerja agar dapat meningkatkan Kinerja Karyawan pada The Medeline Hotel Bengkulu.

2. Hasil penelitian terlihat bahwa pada variabel Disiplin kerja memiliki tanggapan responden yang terendah yaitu 3.45 dikarenakan pimpinan kurang memperhatikan apa yang dibutuhkan oleh karyawan dalam bekerja. Disarankan sebaiknya para pimpinan dapat lebih aktip dalam mencari dan memahami apa yang diinginkan oleh karyawan agar dapat meningkatkan Kinerja Karyawan yang lebih efektif.

3. Hasil penelitian terlihat bahwa pada variabel Lingkungan Kerja memiliki tanggapan responden yang terendah yaitu 3,57 dikarenakan para pimpinan kurang memberikan yang dapat mendukung dalam melakukan tugas dengan mudah dan cepat serta memberikan rasa yang nyaman dalam bekerja serta merangsang minat karyawan 
seperti melakukan kegiatan yang mendukung kinerja. Disarankan pimpinan dapat memfasilitasi sarana dan prasarana sehingga karyawan dapat berkerja dengan baik.

4. Disarankan bagi peneliti selanjutnya khususnya penelitian yang sama perlu dipertimbangkan untuk faktor-faktor lain diluar variabel Disiplin Kerja $\left(\mathrm{X}_{1}\right)$ dan Lingkungan Kerja $\left(\mathrm{X}_{2}\right)$ terhadap Kinerja Karyawan (Y) serta dapat mengembangkan jumlah respondennya sehingga akan menghasilkan penelitian yang lebih baik. 


\section{DAFTAR PUSTAKA}

Anjani, R. (2019). Tata Kelola Adminitrasi Keuangan, Dan Pembangunan Desa Tepi Laut Kabupaten Bengkulu Utara. Jurnal Pengabdian Masyarakat Bumi Raflesia, 2 (2).

Asmawi, M. (2017). The effect of compensation, empowerment, and job satisfaction on employee loyalty. International Journal of Scientific Research and Management, 5(12), 7590-7599.

Alex, S., Nitisemito, 2001. Manajemen Personalia, Ghalia Indonesia, Jakarta.

Anwar Prabu Mangkungara. 2015. Sumber Daya Manusia Perusahaan. Cetakan kedua belas. Remaja Rosdakarya: Bandung.

Arianto, Dwi Agung Nugroho. 2013. Pengaruh Kedisiplinan, Lingkungan Kerja dan Budaya Kerja Terhadap Kinerja Tenaga Pengajar. Jurnal Economia. Vol.9 No.2.

Arida. 2012. Pengaruh Motivasi, Lingkungan Kerja dan Kepemimpinan terhadap Kinerja Karyawan PT. Sai Apparel Semarang. Skripsi.

Arifin, Magfira. 2017. Pengaruh Disiplin Kerja Dan Lingkungan Kerja Terhadap Kinerja Pegawai Pada Kantor Kecamatan Puuwatu. Skripsi. Universitas Halu Oleo Kendari.

Arikunto, S. 2010. Prosedur Penelitian Suatu Pendekatan Praktik. Jakarta: Rineka Cipta.

Arintonang Lerbin R. 2005. Kepuasan Pelanggan. Jakarta: PT Gramedia Pustaka Utama

Azwar, Saifudin. 2009. Metode Penelitian. Yogyakarta: Pustaka Pelajar.

Basuki, Agus Tri and Prawoto, Nano. 2016. Analisi Regresi dalam Penelitian Ekonomi dan Bisnis:Dilengkapi Aplikasi SPSS \& EVIEWS. Depok: PT. Raja Grapindo Persada

Basu Swastha, 2000, Pengantar Bisnis Moderen, Pengantar Ekonomi Perusahaan Moderen, Jakarta: Liberty.

Bernardin, H. John, dan Joyce E.A Russel. (2003). Human resource management (An Experimental Approach International Edition). Mc. Graw-Hill Inc. Singapore.

Ciptoningrum, P. (2013). Petingnya perkembangan Sumber Daya Manusia. Retrieved Februari 28, 2014, from http://www.academia.adu/3841948

Danang, Sunyoto. 2012. Manajemen Sumber Daya Manusia. Jakarta: PT Buku Seru. http://repository.upi.edu/17628/4/S_MBS_1001311_Bibliography

Damayanti, A. P., Susilahningsih, \& Sumaryanti, S (2013). Pengaruh Kompensasi dan Motivasi Kerja Terhadap Kinerja Karyawan Perusahaan Daerah Air Minum (PDAM) Surakarta. Jupe UNS, 2, 155-168

Edi Sutrisno. 2016. Manajemen Sumber Daya Manusia.Jakarta: Prenadamedia Grop. 
Firmansyah, Vidi. 2017. Pengaruh Disiplin Kerja Dan Lingkungan Kerja Terhadap Kinerja Karyawan PT. Neuronworks Indonesia. Pustaka Pelajar. Skripsi. Universitas Widyatama.

Ghozali, Imam. 2011. Aplikasi Analisis Multivariate Dengan Program IBM SPSS 19 (edisi kelima.) Semarang: Universitas Deponegoro.

Gujarati, Damodar. 2012. Dasar-Dasar Ekonomitrika. Jakarta: Penerbit Erlangga.

Halim. 2014. Pengaruh Kompensasi, Disiplin Kerja dan Motivasi Kerja Terhadap Kinerja Karyawan (Studi Kasus pada Karyawan Bagian Produksi PT. Sai Apparel Industrie. Skripsi.

Hasibuan, Malayu. 2012. Manajemen Sumber Daya Manusia Cetakan Ketujuh Belas. Jakarta: PT Bumi Aksara.

Kasmir, Manajemen Sumber Daya Manusia (Teori dan Praktik), Cetakan ke-1, PT Raja Grafindo Persada, Jakarta, 2016.

Kusumah, Wijaya dan Dedi Dwitagama. 2011. Mengenal Penelitian Tindakan Kelas. Edisi: 2. Jakarta: PT. Indeks

Marliana, Mulyadi. 2007. Pengaruh Motivasi dan Disiplin Kerja Terhadap Kinerja Karyawan pada Departemen Weaving PT. Adetex Cabang Banjaran Kab. Bandung. Skripsi.

Mc Daniel, Carl dan Gates, Roger. 2001. Riset Pemasaran Kontemporer, Salemba Empat: Jakarta.

Onsardi, O. (2019). Effect Of Empowerment On Employees Performance (No. v7g9t). Center for Open Science.

Onsardi, O. (2019). Implementasi Manajemen Kinerja Di Universitas Muhammadiyah Bengkulu (No. kzyfx). Center for Open Science.

Onsardi, O. (2018). Loyalitas Karyawan pada Universitas Swasta di Kota Bengkulu. COSTING: Journal of Economic, Bussines and Accounting, 2(1), 1-13.

Onsardi, O. (2019). Implementasi Empowerment Dalam Meningkatkan Kinerja Karyawan (No. bgwju). Center for Open Science.

Pakpahan, D., Rico. 2017. Pengaruh Disiplin Kerja Dan Lingkungan Kerja Terhadap Kinerja Karyawan pada Karyawan Cv. Hamparan Seaga. Skripsi. Universitas Negeri Yogyakarta.

Rivai, Veithzal, dan Sagala, J., Ella. 2011. Manajemen Sumber Daya Manusia untuk Perusahaan, dari Teori ke Praktik. Jakarta: Rajawali Pers.

Robbins, Stephen P. dan Coulter, Mary. 2010. Manajemen Edisi Kesepuluh. Jakarta: penerbit Erlangga

Santoso, Singgih. 2012. Panduan Lengkap SPSS Versi 20. Jakarta: PT. Elex Media Komputindo 
Sari, Tiya Intan Permata. 2018. Pengaruh Lingkungan Kerja Dan Disiplin Kerja Terhadap Kinerja Pegawai Pada Pendidikan Dan Pelatihan Pegawai Kementrian Pendidikan Dan Kebudayaan. Skripsi. Universitas Islam Negeri Syarif Hidayatullah Jakarta.

Surya Sarjito, Ruliana Ruty, dkk (2017) Pengaruh Perputaran Kas dan Perputaran Persediaan Terhadap Profitabilitas. Akuntabilitas: Jurnal Ilmu Akuntasi. Volume 10 (2) Oktober. 2017.

Sarman. 2012. Pengaruh Lingkungan Kerja Dan Motivasi Kerja Terhadap Kinerja Pegawai Pada Badan Pusat Stastistik (BPS) Kota Kediri. Skripsi

Sedarmayanti. (2011). Manajemen Sumber Daya Manusia, Reformasi Birokrasi Dan Manajemen Pegawai Negeri Sipil (cetakan ke5). Bandung: PT Revika Adi Tama.

Setiawan, Ferry dan Dewi, Kartika (2014) Pengaruh Kompensasi Dan Lingkungan Kerja Terhadap Kinerja Karyawan pada CV. Berkat Anugrah. Jurnal. Denpasar: Universitas Udayana.

Siagan, Sondang. P. 2014. Manajemen Sumber Daya Manusia. Jakarta: Bumi Aksara.

Sopyandi, Herman. 2008. Manajemen Sumber Daya Manusia. Yogjakarta: Graha Ilmu.

Sugiyono. 2010. Metode Penelitian Pendidkan Pendekatan Kuantitatif, Kualitatif, dan R\&D. Bandung: Alfabeta.

Taufik Ismail, Ahmad. 2013. Pengaruh Lingkungan Kerja dan Karakteristik Pekerjaan Terhadap Kinerja Pegawai Pada Dinas Perhubungan Provinsi Sulawesi Tenggara. Skripsi.

Tika H. Moh. Pabundu, 2006. Budaya Organisasi dan Peningkatan Kinerja Perusahaan. Cetakan Pertama. PT Bumi Aksara, Jakarta.

Wirawan, Fajar. 2015. Pengaruh Gaya Kepemimpinan Dan Motivasi Kerja Terhadap Kinerja Karyawan pada PT. Warna Alam Indonesia. Skripsi. Diponegoro. Universitas Diponegoro.

Wilson, Bangun. Manajemen Sumber Daya Manusia, PT Gelora Aksara Pratama, 2012. 